\title{
PHILIP RIEFF
}

Tekst został przetłumaczony na podstawie: Ph. Rieff, Freud: The Mind of the Moralist, Chicago-London 1979, s. 220-256. Serdecznie dziękujemy University of Chicago Press za zgodę na publikację tłumaczenia.

\section{Polityka i jednostka}

Pierwsze Prawo Polityki mówi, że ciało polityczne jest podzielone na klasę rządzącą i klasę rządzoną. Ludzie rodzą się dziećmi... Mogą przetrwać tylko w żłobkach, na których działanie nie maja wpływu... Każde ciało polityczne jest złożone, poza wszystkim innym, ze żłobka, to znaczy klasy rządzonych... i klasy rządzacej.

R. G. Collingwood

Badania polityczne przez niemal cały wiek, jeśli liczyć od Fouriera i Ben-

D thama do sukcesu Freuda, za swój przedmiot obierały głównie instytucje. Fourier w projekcie swej utopii zaakceptował człowieka w całej jego niedoskonałości, oczekując, że to udoskonalenie warunków życia i pracy zmieni jednostkową wadę w społeczną cnotę. Także Bentham nie podjął się próby rozwiązania wielkiej zagadki istoty człowieczeństwa, przekazując ją religii. W zamian skupił się na permanentnej reformie instytucji. Największa ilość szczęścia największej liczby istot nigdy nie była celem psychologii jednostki, pomimo że recepta Benthama, jak na ironię, po 1832 roku stawała się coraz bardziej aktualna. Działania jednostki w społeczeństwie masowym można było w coraz większym stopniu rozpatrywać przez pryzmat ilości. Chciała więcej, a dostawała mniej.

Reforma instytucji, która według zamysłu liberałów i radykałów miała prowadzić do prawdziwej i trwałej odmiany społeczeństwa ludzkiego, nie wytrzymała próby wydarzeń. W obliczu takiego stanu rzeczy liberalizm wy- 
cofał się na pozycje, w obszarze których psychoanaliza jest nie tylko najbardziej wpływowa, ale i najłatwiejsza do przyswojenia. Analiza polityczna u Freuda powraca do formy archaicznej, nieredukowalnej dychotomii - Jednego i Wielu. Analiza ta zastosowana do badania społeczeństwa podążą więc drogą dobrze znaną, rzec można: nawet tradycyjną pośród innych odmian teorii polityki. Poszukuje ona wolnej przestrzeni pomiędzy podstawowymi i niemoźliwymi do pogodzenia jednostkami analizy. Na tym właśnie polega atrakcyjność teorii Freuda i jedno z możliwych wyjaśnień zasięgu jej wpływów. Freud zamiast zerwać, odnawia dualizm antycznej teorii polityki, który nigdy nie uległ wyczerpaniu, pojawiając się później w różnych wcieleniach. Teoria polityki w starym stylu zyskuje nowe życie dzięki psychologii moralnej austriackiego myśliciela. Owa psychologia moralna przekonuje, że jest on raczej bliższym epoce parodystą naszego charakterystycznego sposobu moralizowania aniżeli wynalazcą nowego stylu moralizatorstwa.

\section{I}

Rozszerzając swą psychologię jednostki na badanie zbiorowości, Freud powiela te same sprzeczności i ambiwalencje, zrozumienie wolności i represji, które odnotowaliśmy wcześniej. Jego psychologia początkowo wydaje się opierać na naturalistycznym, bezpośrednim opisie „niskiej” natury ludzkiej, niekoniecznie uszlachetnianej przez otaczającą ją kulturę. Jednak w psychologii, której cechą charakterystyczną jest spostrzeżenie, mówiące o napięciu pomiędzy społecznym „szczytem” a naturalnym „dnem”, ostateczna aprobata moralna może wyglądać inaczej. Ogólnie rzecz biorąc, Freud zgadza się z Hobbesem, że człowiek jest istotą anarchiczną, a społeczeństwo go mityguje, odrzucając pogląd Rousseau, iż człowiek jest dobry, a społeczeństwo go demoralizuje. Takie ujęcie tematu nie może jednak być ostateczne, gdyż nie jest wystarczająco dialektyczne. Psychologię społeczną Freuda, podobnie jak biologię Darwina, należy zbadać dokładniej, a nie tylko poddać ją Hobbesowskiej interpretacji.

Uczestnictwo w każdej wspólnocie jest dla Hobbesa chwilowym i ograniczonym zobowiązaniem, nie zmieniającym w żaden istotny sposób samotniczego i nastawionego na prywatność usposobienia ludzi, którzy „nie znajdują przyjemności w życiu gromadnym (przeciwnie, raczej znajdują wiele przykrości), gdzie nie ma mocy, która by była zdolna trzymać w strachu ich wszystkich". Także Freud uznaje, że człowiek naturalny jest trwale niespołeczny. Moim zdaniem psychoanaliza dużo subtelniej wyjaśnia, w jaki sposób antyspołeczna jednostka jest wszczepiana w tkankę społeczną, aniżeli najbardziej naturalistyczne ujęcia motywacji ludzkiego działania. Homo homini lupus - słowa Hobbesa odbijają się szerokim echem w psychologii spo- 
łecznej Freuda. Człowiek naturalny jest pazerny i egocentryczny. Freud jednak zauważa także naturalną towarzyskość człowieka i jego stałą emocjonalną potrzebę wspólnoty. Człowiek naturalny jest instynktownie libidalny, jest istotą urodzoną w hierachii miłości, co dalece modyfikuje ujęcie Hobbesa. Używając metafory Freuda, w rodzinie nie istnieje jedynie rywalizacja rodzeństwa, czyli wzór społecznego rozdrobnienia, lecz także naturalna miłość i zależność od rodziców. Człowiek od początku popada w niewolę społeczną, rodząc się w społeczności rodziny. Twórca psychoanalizy zgadza się z Hobbesem, podkreślając, że agresywność jest podstawową cechą człowieka, jednak komplikuje jego twierdzenie, że przebiegłość i siła to jedyne prawa, otrzymywane w naturze. Potwierdza, że w naturze istnieją siła i wolność, lecz dodaje do nich także miłość i władzę. Najwyższym prawem jest prawo „pierwotnej ambiwalencji”, które każdemu uczuciu nienawiści przeciwstawia uczucie miłości, każdy akt agresji pęta późniejszym ciężarem winy.

Hobbes i Freud nie byli zadowoleni z założenia, że życie społeczne jest ustanawiane na fundamencie nagiej siły. Obaj wyobrażali sobie, że państwo założono na bardziej trwałej podstawie, na zawarciu „swego rodzaju umowy społecznej”" Zauważmy jednak pewną różnicę. Celem teorii umowy społecznej, w jej wszystkich odmianach u Hobbesa, Locke’a czy Rousseau, było wskazanie pierwotnej prawowitości społeczeństwa, a nie przedstawienie jego historycznych początków. Póżniejsza, antropologiczna fikcja umowy społecznej, którą Freud przedstawił w swoim micie początków, miała pełnić inną funkcję. Problem prawowitości nie zajmuje go wcale, gdyż nie jest on filozofem polityki. Jego celem jako psychologa jest odsłonięcie źródeł porządku społecznego. Powodem zawarcia porozumienia społecznego u autora Lewiatana była roztropność, rodzaj strachu. Roztropna rachuba niebezpieczeństw wynikających z anarchii powoduje, że wszyscy przemyślnie przekazują swoje prawa jednemu, który zostaje obarczony odpowiedzialnością za ochronę wszystkich przed zagrożeniem ze strony wszystkich. Freud nie przypisuje działaniu człowieka naturalnego aż tak racjonalnego charakteru, więc buduje teorię umowy społecznej na innym twierdzeniu dotyczącym natury ludzkiej. Jego zdaniem społeczeństwo polityczne to wyraz irracjonalnej tęsknoty człowieka za autorytetem, a nie artefakt zaprojektowany przez strach i roztropność w celu ograniczenia powszechnego egoizmu. Pierwotny ojciec zostaje zamordowany, co powoduje z biegiem czasu „nadzwyczajne nasilenie tęsknoty za ojcem".

S. Freud, Człowiek imieniem Mojżesz a religia monoteistyczna, [w:] tenże, Pisma społeczne, przeł. A. Ochocki, Warszawa 1998, s. 453.

Tenże, Totem i tabu. Kilka zgodności w życiu psychicznym dzikich i neurotyków, przeł. M. Poręba, R. Reszke, [w:] tenże, Pisma..., s. 365. 
Rządy zatem nie rodzą się z umowy społecznej. W opisie Freuda taka umowa pojawia się jako reakcja na obalenie rządu patriarchalnego. Nie jest ona realizacją roztropności grupy, reprezentuje zaś większościową wolę współobywateli jedynie w ściśle określonym sensie. Psychoanaliza pozwala zatem zreinterpretować mity umowy społecznej jako umocnienie woli ojca wymierzonej przeciw buntowniczym impulsom skarconego synostwa. Prawo pierwotnej ambiwalencji realizuje się, zrównując bunt $\mathrm{z}$ winą, a agresję $\mathrm{z}$ uległością. Umowa społeczna symbolizuje proces wejścia społeczeństwa w strukturę historyczno-polityczną, przez co nie oznacza zwycięstwa wielu, lecz ich pierwszą i wzorcową porażkę. Przez nałożenie nowych ograniczeń dotyczących zachowań seksualnych (nakaz totemicznej egzogamii) „nikt nie mógł, czy też nikomu nie było wolno osiągnąć pełni władzy ojca, choć wszyscy do tego dążyli”" . Odtąd pragnienie każdego z braci, by rządzić, mogło się realizować w ograniczonym stopniu jedynie w rodzinie każdego z nich.

Ograniczanie wolności działania jest więc według Freuda celem każdego autorytetu we wszystkich formach zbiorowości - w hordzie, w rodzinie, w rządzie - jest cechą, która ją określa. Granice wolności mogą zmienić lub uściślić racjonalna krytyka albo irracjonalny impuls, lecz ludzie rzadko formułują racjonalną krytykę, zaś wybuchy ich impulsów są ostrożne i zgodne z konwencjami. W najlepszym razie jeden zbiór restrykcji może zostać zastąpiony innym. Wolność obwarowana trwałymi zastrzeżeniami ogranicza się więc do możliwości zmiany panów. Wolność jednostki nigdy nie była celem jakiegokolwiek społeczeństwa. Wypowiedziane lub niewypowiedziane, założenie to jest charakterystyczne nie tylko dla Freuda, lecz także dla całej teorii polityki od Platona do Marksa, pozostając wszelako obcym dla najgłośniejszych współczesnych nurtów myśli społecznej. Historycy, mówiąc o upadku danej instytucji, takiej jak np. średniowieczny Kościół, mają na myśli przede wszystkim rozpad jej władzy i popadnięcie w niemoc. Upadek jednej instytucji zwiastuje rozkwit innej, w tym historycznym przypadku państwa. Podobnie socjologiczny obraz upadku współczesnej rodziny jest aktualnym przykładem zmierzchu władzy instytucjonalnej. Osłabieniu autorytetu rodzicielskiego, przejawiającemu w zaniku możliwości ograniczania wolności i kształtowania moralnych upodobań najmłodszych członków rodziny, towarzyszy rozkwit władzy grup rówieśniczych. Freud jednak wykracza poza ogólne stwierdzenia historyków i socjologów, opisujących relacje między instytucjami społecznymi. Przekonanie, że wszystkie relacje społeczne, w całej swej różnorodności, są ufundowane na mechanizmach autorytetu, oparte jest na obrazie związku pomiędzy polityką a człowiekiem 
prymitywnym, jaki szkicuje on, korzystając z ustaleń ówczesnej antropologii.

Freud wyjątkowo silnie podkreśla represyjny charakter społeczności prymitywnych, poszukując w nich wzoru represyjności wszystkich społeczeństw. Znaczna część Totemu i tabu zostaje poświęcona zobrazowaniu wspomnianej surowości prymitywnego porządku społecznego. Nigdzie indziej społeczeństwo jako narzędzie represji nie zostaje opisane bardziej jednoznacznie. W opisie surowości i znojności życia w kulturach prymitywnych autor idzie za twierdzeniami współczesnych mu antropologów, jednak opisując zahamowania prymitywne jako wzory współczesnych neuroz, ze swym pesymizmem dalece wykracza poza ich ustalenia. Dokonuje śmiałej i dwuznacznej oceny idei regresu i stałości, roztaczając perspektywę prowadzącą nie tylko od prymitywnych ograniczeń do współczesnych neuroz, lecz także do „zakazów moralnych i obyczajowych, których sami przestrzegamy” ${ }^{4}$. odrzucenie i tabu, postrzegane przez antropologów jako najwcześniejsza metoda dyscypliny społecznej, Freud uznaje za wzorce wszelkiej dyscypliny społecznej i wyparcia naturalnych impulsów.

Autor Totemu i tabu, podobnie jak Emil Durkheim, używa wyników badań kultury prymitywnej do sformułowania tezy dotyczącej dyscypliny społecznej. Durkheim wypunktował bowiem sposoby, jakimi posługiwały się społeczeństwa prymitywne, by zdławić w rodzących się jednostkach wszelkie potrzeby społeczne i ograniczyć ich działania. Freud zaś podkreśla, że prawo prymitywne ma dalece zakazujące i ograniczające inklinacje. Między tymi dwoma badaczami zachodzi jednak ważna różnica. Durkheim zakłada istnienie świadomości zbiorowej pośród prymitywnych, toteż historia ludzka jest dla niego historią indywiduacji. Freud z kolei przyjmuje, że za każdą formą świadomości czai się działająca instynktownie jednostka, w której funkcjonowanie społeczeństwo ingeruje od zawsze w ten sam sposób ${ }^{5}$. Człowiek prymitywny opisany w Totemie $i$ tabu w niewielkim stopni różni się od człowieka nowoczesnego. W człowieku prymitywnym nie ukrywa się jednak człowiek nowoczesny, podczas gdy większość współczesnych typów charakterologicznych, neurotyków, jest trapiona przez istnienie wewnętrznego,

Tamże, s. 264.

Inna różnica pomiędzy Freudem a Durkheimem polega na tym, że ten drugi, jako socjolog, próbował głównie rozróżnić historyczne formy prawa. Ściślej mówiąc, zajmował się ewolucją od droit repressif (prawo karne, które dominowało w społeczeństwie prymitywnym) do droit restitutif (nowoczesne, kontraktualne prawo występujące w społeczeństwie, wyróżniającym się podziałem pracy). Freud z kolei na drodze rozumowania genetycznego doszedł jeśli nie do negacji różnic pomiędzy prawem prymitywnym a nowoczesnym, to przynajmniej do ignorowania ich w ramach skłonności do podkreślania innych podobieństw. 
zapoznanego prymitywa. Pozostałości tego istnienia znaczą wszystkich współczesnych, dlatego wszyscy to utajeni neurotycy.

Totem $i$ tabu jest więc tak naprawdę alegorią współczesności, która uczy nas, że władza jest konieczna. Freud w surowości przepisów prymitywnego prawa nie znajduje dowodu na pierwotną troskę, która wzajemnie łączyła ludzi. Istnienie tabu wskazuje według niego raczej na niemożliwą do wykorzenienia, ludzką skłonność do anarchii. Skoro jednostki są nieustannie skore do buntu, społeczeństwo musi je poskramiać. Austriacki badacz zgadza się więc ze spostrzeżeniami Frazera poczynionymi w The Magic Art and the Evolution of Kings: „Prawo jedynie zakazuje ludziom robić to, do czego skłaniają ich popędy; to, czego sama natura zakazuje i za co karze, nie musi być już zabraniane i karane przez prawo. Wobec tego w każdym wypadku możemy spokojnie przyjąć, że zbrodnie zakazane przez prawo to te zbrodnie, do których popełnienia wielu ludzi przejawia naturalną skłonność"

Prawo świadczy o sile ukrytych i niesłabnących pożądań, o „potrzebie wewnętrznej, w którą brak świadomego wglądu". Freud uważa, że istnienie pożądania świadczy o potrzebie istnienia prawa. Brak świadomości pragnień jest usprawiedliwieniem dla skomplikowanego systemu zakazów społeczeństw zarówno prymitywnych, jak i współczesnych.

Jednak to przede wszystkim jeden zakaz jest podstawą koncepcji działających instynktownie jednostek. Chodzi o tabu kazirodztwa: „Zamiast wnioskować na postawie prawnego zakazu kazirodztwa, że istnieje naturalna niechęć do kazirodztwa, powinniśmy raczej przyjąć założenie, że pobudza do niego naturalny instynkt, skoro zaś prawo tłumi kazirodztwo - jak inne popędy naturalne - to czyni tak dlatego, że ludzie cywilizowani doszli do wniosku, iż zaspokojenie tych naturalnych popędów jest szkodliwe dla powszechnego dobra społeczeństwa"

Formalna uniwersalność przymusu, łącząca zarówno prymitywne dążenia, jak i nowoczesne kaprysy (labirynt miłosnych uczuć do matki i zazdrość żywiona wobec ojca, która osiąga punkt kulminacyjny w kompleksie Edypa), może zostać poddana w wątpliwość. Trudno jednak nie zgodzić się z Freudem, że antypatie społeczne i prywatne nie mają dla społeczeństwa żadnej wartości nominalnej.

Wkład Freuda w negatywną interpretację prawa, inspirowaną pierwotnie Frazerem, polega więc głównie na zrównaniu współczesnych przypadków neurotyzy z prymitywną etykietą zachowań. Autor Totemu i tabu przekształca prawo w owoc negacji instynktownych działań jednostki. Freud nie opisuje jednostki jako całkowicie anarchicznej. Dopóki pragnienie po-

Cyt. za: S. Freud, Totem i tabu, s. 346.

Cyt. za: tamże. 
gwałcenia prawa - chęć zabicia ojca i spółkowania z matką, czyli klasyczna fantazja edypalna - utrzymuje się w obszarze nieświadomości, posłuszeństwo jest pragnieniem pozytywnym. Porównując dobrowolnie narzucone zakazy, poprzez które neurotycy sami powstrzymują zabronione popędy oraz misterne rytuały, powstrzymujące z kolei nieład moralny wśród ludzi prymitywnych, Freud buduje dialektykę, zgodnie z którą ,ja” pragnie własnego ograniczenia. Automatycznie pojawiają się jednak sprzeczne uczucia, które równoważą wyrzuty sumienia, a to z kolei prowadzi do uznania „wyrzeczenia się jakiegoś dobra lub wolności" jako psychologicznie doświadczanej represji, zobiektywizowanej w instytucji tabu lub prawa. Ambiwalencja i tabu (czytaj „prawo” lub „represja”) mogą wydawać się enigmatyczne i niczym nie umotywowane, jeśli nie zostaną odczytane w świetle najbardziej uniwersalistycznych wyjaśnień Freuda. Jednak poprzez uznanie tejże ambiwalencji dialektyka represji i buntu, leżąca u podstaw historii kultury, staje się niezniszczalna. Każdy nowy objaw rozluźnienia obyczajów jest odpierany ustanowieniem kolejnej represji ${ }^{9}$. W walce prawa i popędu nie ma ani zwycięzcy, ani pokonanego. Tylko „ja”, w roli arbitra w życiu psychicznym, może rozwiązać sytuację patową, wpisując potrzeby wewnętrzne i przyswojone ograniczenia $\mathrm{w}$ ich sprawiedliwe artykulacje wyrażone $\mathrm{w}$ ramach racjonalnego kompromisu. Owa nadzieja, kryjąca się w rozumie, pozostaje w obrębie pola analizy Freuda. Analiza ta w przeważającej części opiera się jednak na wizji natury ludzkiej, w ramach której przymus oraz bunt wydają się równie nieodzowne.

Psychologizując zjawiska buntu i przymusu społecznego, Freud zwraca się przeciwko popędowi na rzecz prawa. Społeczeństwo jest represyjne, lecz bunt nie jest usprawiedliwiony. Wolność, której poszukuje człowiek, jest zawsze wolnością stania się panem. „Świadome pobudki” prowadzące do buntu mają swoje nieświadome źródła w zawiści. Żądza władzy jest „zaraźliwa". Każdy jest narażony na tę zarazę i nikt nie jest na nią immunizowany; „każdy zapewne chciałby być królem" ${ }^{\text {.10 }}$ Zazdrość jest namiętnością słabych, nie rozpala natomiast silnych. Nawet w wymyślnych uprzejmościach okazywanych przywódcom odnaleźć można dowody zawiści. Szacunek, poważanie, zasady etykiety wywodzą się z „obawy przed zetknięciem się" z różnymi osobami - władcami, zmarłymi, nowonarodzonymi - wobec których człowiek prymitywny żywi nieświadomą wrogość. Z uwagi na to, że wszystkie

\footnotetext{
8 Całe omówienie problematyki prymitywnego tabu w Totemie $i$ tabu jest ważne jako historyczny prototyp najważniejszej kategorii psychologicznej Freuda - represji.

S. Freud, Totem i tabu, s. 273.

Tamże.
} 
oznaki posłuszeństwa są ambiwalentne, szacunek i sympatia wobec potężnych muszą skrywać nieuświadomioną wrogość.

Rzucenie wątpliwości na pobudki uzasadniające sprzeciw wobec autorytetu to subtelna i odświeżająca część psychologii politycznej Freuda. W jej obrębie odnaleźć jednak można także rzucone mimochodem uwagi, świadczące o sympatii z buntownikami i samym buntem, spowodowanym zarówno represjami, jak i instynktem. Złamanie prawa może być nie tylko jałowym gestem wynikającym z osobistego nieprzystosowania, lecz także usprawiedliwionym rozerwaniem więzów kulturowego ucisku. Choć Freud oddawał cześć bohaterskim prawodawcom takim jak Mojżesz, postrzegając ich jako twórców kultury, to jednak rozumiał heroicznych prawołomców, którzy wstrząsali tą kulturą i wyzwalali ludzkie instynkty. Nawet tak nieprzyjemna postać jak Ryszard III Szekspira spotyka się z pewną dozą współczucia Freuda. W osobie oszpeconego króla widział Freud przykład uśpionego dążenia wszystkich, by stać się „wyjątkowym, lekceważyć skrupuły, które hamują innych". Uwagi Freuda na temat Ryszarda III są bardzo podobne do ocen Adlera. Żądza władzy jest zrozumiałą reakcją na wcześniejsze krzywdy. Każda rola w spektaklu domaga się odpowiedniej reakcji ze strony publiczności. Tak oto Freud tłumaczy siłę oddziaływania Szekspirowskiego portretu złego króla: każdy, kto został skrzywdzony, „zrozumie współczucie, wzbudzające sympatię nawet dla takiego łotra jak on"11.

\section{II}

Żadne inne dzieło Freuda nie zostało tak jednomyślnie odrzucone jak Totem i tabu. Po jego wydaniu rytuałem antropologów i innych teoretyków społecznych stało się metodologiczne miażdżenie dzieła ich wielkiego ojca. Totem i tabu stało się fikcją, odzwierciedlającą tylko mroczne uprzedzenia Freuda. Tezy w nim wyłożone jeśli miały jakiekolwiek zastosowanie, to tylko do prostych grup społecznych takich jak rodzina, lecz z pewnością nie do społeczeństwa z całą z jego złożonością, czy to w wersji prymitywnej, czy cywilizowanej. Dekadę po publikacji książki, w odpowiedzi na krytykę, Freud porzucił sztafaż domniemanej prehistorii. Psychologia zbiorowości i analiza ,ja” (1921) zawiera ukryte próby obalenia zarzutów wysuniętych wobec Totemu i tabu. Tym razem Freud wystąpił z propozycją obrania za punkt wyjścia nie „względnie prostej formacji zbiorowej, lecz... zbiorowości wysoce zorganizowanych, trwałych i sztucznych" ${ }^{12}$. Pomimo że w ten sposób porzucił ewo-

11 S. Freud, Some Character-Types Met with in Psycho-Analytic Work, [w:] tenże, The Standard Edition of the Complete Psychological Works of Sigmund Freud, red. J. Strachey, t. XIV, London 1953, s. 314-315.

12 Tenże, Psychologia zbiorowości i analiza ,ja", [w:] tenże, Pisma..., s. 75. 
lucjonistyczną fascynację naszymi korzeniami dla bardziej współczesnego sposobu analizy, już w tytule nowego dzieła zawarł znamienny przesąd. Angielskie słowo group nie oddaje bezpośredniego politycznego sensu niemieckiego terminu Massen, oskarżanego o reakcyjne konotacje w psychologii politycznej, głównie francuskiej i włoskiej, popularnej na przełomie wieków.

Origins of Contemporary France (1868) Taine'a jest zapewne najwcześniejszym przykładem tego sposobu myślenia i odsłania jego najgłębsze uprzedzenia, sprzeciw wobec rewolucji francuskiej i jej wszystkich konsekwencji. Według konserwatywnych obserwatorów rewolucja mieszczańska dziewiętnastego wieku wyzwoliła emocje mas, będące zupełnie nową siłą, dalece silniejszą niż historyczne instytucje czy idee polityczne. Co znamienne, włoscy pionierzy tej szkoły myślenia, tacy jak Lombroso w latach 80. XIX wieku, włączali psychologię mas w obręb nowej nauki zwanej „antropologią przestępczą". Oznaczało to badanie życia tłumu z kryminologicznego punktu widzenia. Sentymenty elit nie były niczym osobliwym w dziewiętnastowiecznej teorii społecznej. Znamienne jednak, że przybrały one formę naukowej psychologii społeczeństwa. Podkreślanie roli owej nowej psychologii było nieznanym akcentem w porównaniu do wcześniejszych typów konserwatyzmu oraz postępem w stosunku do skostniałego legalizmu, który charakteryzował ówczesną teorię politykę. Różnica pomiędzy legalistyczną a psychologiczną teorią polityki leży w intuicji, że instytucje - kościoły, armie, partie - tak naprawdę znaczą w polityce mniej niż emocje skonfliktowanych grup kulturowych. Psychologiczne podejście do polityki łączy Freuda z umysłami o szczególnych i częstokroć reakcyjnych skłonnościach (Taine, Bagehot, Lombroso, Sighele, Le Bon, Bernheim). Choć dzieli ich wiele, wszystkich łączy z Freudem zainteresowanie tak zwaną „polityką kulturową"13.

W swej psychologii politycznej Freud nie był odkrywczy. Osobliwa mieszanka podejrzliwości i sympatii do mas jest obecna w wielu innych, zarówno dobrych, jak i złych, pismach politycznych schyłku dziewiętnastego wieku. Podejrzliwość pojawia się w nich częściej niż sympatia. Po roku 1848, a następnie po Komunie Paryskiej, rozczarowanie demokracją zapanowało nawet pośród tych intelektualistów, którzy nawoływali do rewolucji lub przynajmniej je wspierali. Zawód ten wynikał ze skupienia się na doświadczeniu demokracji we Francji, podobnie jak dzisiaj spotykamy się z typowym pesymizmem, bedącym następstwem rezultatów rewolucji bolszewickiej. Umiarkowane rozczarowanie chwiejnością demokracji pojawiało się nawet

13 Jest to choćby wynik tego, że antysemityzm - niezależnie od tego, czy z inspiracji freudyzmem - przestał być w ostatnich latach traktowany jako problem peryferyjny, lecz kluczowy dla badań współczesnego życia politycznego. 
w pismach angielskich krytyków społecznych takich jak Walter Bagehot (wnikliwe listy wydane jako Amicus) czy Lord Bryce (wielki esej Obedience), jednak przybierało ono dużo mroczniejszy, polemiczny wyraz w wyobraźni pisarzy kontynentalnych. Było to zapewne dziedzictwem rewolucji chwalebnej, która w pamięci Anglików rozstrzygnęła wiele problemów. Na kontynencie wszelako liberalne rewolucje ponosiły porażki, zwiastując nadejście skrajniejszych alternatyw.

Dobrym przykładem tego typu antyrewolucyjnej frazeologii jest fragment listu Freuda, napisanego zimą przełomu lat 1885-1886, którą spędził, studiując medycynę w Paryżu. Zwracając się do swojej przyszłej żony, Freud opisuje swe wrażenia następująco: „Miasto i zamieszkujący je ludzie są niesamowici. Wydaje się, jakby należeli do innego gatunku, jakby zostali opętani przez tysiąc demonów. Zamiast «Monsieur» i «Voila l'Echo de Paris», nieustannie słyszę «A la lanterne» czy «A bas dieser und jener». To ludzie opanowani psychiczną epidemią, znajdujący się w historycznym, masowym spazmie" $^{\text {14 }}$.

W okresie pomiędzy młodzieńczą retoryką a późniejszą psychologią naukową Freud przetłumaczył dwie książki Bernheima dotyczące sugestii i czytał prace akademickich psychologów społecznych takich jak William McDougall. Według niego samego to właśnie The Group Mind (1920) McDougalla była bodźcem, który z powrotem zainteresował go psychologią zbiorowości. Psychologia zbiorowości i analiza , ja”, napisana w roku 1921, oparta na tych właśnie wpływach, wydaje się nosić także pewne ślady jego młodzieńczych ułud, według których Paryż to wciąż miasto rewolucji i Komuny Paryskiej. Freud prawdopodobnie w ogóle nie zastanawiał się nad zgodnością swojej pogardy wobec mas i wspomnianych wpływów, na których budował swe założenia. W Psychologii zbiorowości spotykamy się więc z całymi fragmentami jakby przepisanymi z Psychologii tłumu (1895) Le Bona, dzieła będącego wyrazem najbardziej antydemokratycznej krytyki, podnoszonej do poziomu psychologii społecznej. Dług Freuda zaciągnięty u tego głośnego rasisty i pisarza francuskiej klasy wojskowej odzwierciedla rzecz jasna jego podziw dla autorytetu, kryjący się pod krytyką społeczeństwa represyjnego. Nie zmienia to faktu, że praca Freuda pozostaje zabarwiona autorytarnymi inspiracjami jego poprzedników, które nie są wcale niegroźne.

Wszystkie poglądy wyrażone we wcześniejszych pracach w Psychologii zbiorowości i analizie "ja" zostają przeformułowane $\mathrm{w}$ celu skupienia się na

E. Jones, Sigmund Freud: Life and Work. Vol. 1: The Young Freud 1856-1900, London 1953, s. 184. By odnaleźć inne konwencjonalne ślady fantazji Freuda dotyczących rewolucji francuskiej, zob. jego uwagi o śnie Maury'ego o gilotynowaniu. S. Freud, Objaśnianie marzeń sennych, przel. R. Reszke, Warszawa 1996, s. 418-419. 
jednym stronniczym twierdzeniu. Obraźliwe oceny zbiorowości, porównania do dzieci, dzikich i neurotyków zostają tutaj zaostrzone, zwłaszcza w zestawieniu z ocenami jednostki. Zbiorowość zostaje zdefiniowana jako idealne przeciwieństwo jednostki. Jej cechą charakterystyczną jest więc erupcja nieświadomych pragnień oraz „silne więzi uczuciowe”, które pozbawiają indywidua „oryginalności i odwagi osobistej”. W ramach zbiorowości „nikną wszekie zahamowania indywidualne, a do swobodnego zaspokojenia popędowego budzą się wszystkie okrutne, brutalne, destruktywne instynkty, które drzemią w człowieku jako pozostałości praczasu"

Różnica pomiędzy tym stanowiskiem a jego wcześniejszymi wersjami polega na tym, że Freud, koncentrując się na prymitywnej irracjonalności tłumu, nie formułuje aktu oskarżenia wobec historii, wyrzekając się pociechy, którą zaoferował Le Bon. Le Bon i inni byli wstrząśnięci jedynie kształtem polityki demokratycznej, a nie polityki w ogóle. Nie zdając sobie sprawy z rozróżnień na „lud” i „masę” czy „obywateli” i „motłoch”, obecnych w teorii demokracji w czasach antycznych, Freud sądził, że dokonał odkrycia świadczącego o trwałej obecności barbarzyństwa w życiu zbiorowości. Autor Totemu i tabu nie wierzył w istnienie niezależnego, inteligentnego obywatela, hołubionego przez Rousseau, podobnie jak uświadomionego proletariusza z Marksowskiego utopizmu. Poszukując uczuciowych prądów płynących pod powierzchnią ideologii i instytucji, nie znalazł powodu, by uznać umysł zbiorowy za wytwór społeczeństwa przemysłowo-miejskiego. Motłoch, będący według Burckhardta czy Nietzschego nowym zagrożeniem dla kultury europejskiej, którego marksistowski proletariat miał być wyzywająco stanowczym wcieleniem, Freud postrzegał jako wspólny element każdej polityki.

Różnica pomiędzy Psychologia zbiorowości i analiza , „ja" a stanowiskiem Le Bona jest warta odnotowania, gdyż tylko dzięki pominięciu historycznego procesu wzrostu znaczenia mas Freud mógł włączyć pewne antydemokratyczne obawy, żywione przez wcześniejszych pisarzy, w swą własną niechęć wobec polityki. W opinii Freuda zadaniem psychologii nie jest usprawiedliwianie obaw konserwatystów czy potępianie nadziei radykałów (do których miał ambiwalentny stosunek), lecz opis procesu, w czasie którego racjonalne jednostki pogrążają się w barbarzyństwie pod jarzmem życia zbiorowego. $\mathrm{Z}$ perspektywy indywidualistycznej, jego psychologia formułuje pytania, jak i dlaczego jednostki gromadnie odczuwają, myślą i działają w niezgodzie ze swymi odrębnymi ,ja".

Le Bon zakładał, że w tłumie działają nieuświadomione uczucia, co podobnie jak dla Freuda - oznacza cofnięcie się do prymitywnego stanu

Tenże, Psychologia zbiorowości i analiza ,.ja”, [w:] tenże, Pisma..., s. 61. 
umysłu. Jednak wizja ponownego rozkwitu nieświadomości nie jest odpowiedzią na problem transformacji osobowości, lecz jedynie ponownym przedstawieniem tego problemu. Dlatego też Freud odrzuca ją. Odrzuca także przekonującą tezę, że w tłumie rodzi się nowy umysł zbiorowy odmienny od umysłów jednostek tworzących ten tłum. Zgadzając się, że pewne treści obecne w nieświadomości są kolektywne, Freud nigdy nie posunął się do użycia pojęcia międzyjednostkowej psychiki, którą później ożywił Jung ${ }^{16}$. Wyjaśniając podwójną metamorfozę każdej osoby w tłumie polegającą na

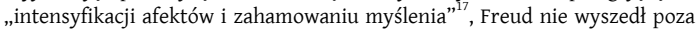
tezę o powielaniu i zgodności jednostkowych procesów psychicznych. Próbował zatem wyjaśnić pewne procesy psychologii zbiorowości na gruncie jednostkowych aktów identyfikacji z przywódcą lub zasadami przezeń narzuconymi, uznając współdzielenie tej samej sytuacji emocjonalnej za sprawę drugorzędną.

Freud odrzucił też koncepcję „oddziaływania sugestywnego", która często bezzasadnie jest postrzegana jako sprzeczna z tezą o istnieniu umysłu zbiorowego. W ramach tego stanowiska barbarzyńskie skłonności tłumu są następstwem hipnotycznego bodźca wysyłanego przez jego otoczenie uczuciowe oraz ochronnej nieokreśloności mas, oplatającej bezkrytyczną („łatwo ulegającą sugestiom”) część każdego umysłu jednostkowego. Bagehot i Tarde nazwali tę tendencję „naśladownictwem” lub „nieświadomym naśladownictwem". Dopiero jednak gdy hipnoza, mocą niezależnych wysiłków Charcota i Bernheima we wczesnych latach 80. XIX w., została uznana za metodę nieomal naukową, demoniczny obraz hipnotyzera stał się znakiem firmowym polemik konserwatystów. „Sugestia” zastosowana wobec osób o słabym umyśle sprawiła, że utworzyły one tłum, który - zahipnotyzowany - stał się jednym silnym umysłem ${ }^{18}$. Freud nie widział żadnej jakościowej różnicy pomiędzy związkiem hipnotycznym, osiąganym w klinice, a uczuciową organizacją społeczeństwa. „Związek hipnotyczny jest - jeśli można wyrazić się

${ }^{16}$ Idea ta ma czcigodnych poprzedników w niemieckim życiu intelektualnym, począwszy od „duszy ludu" Herdera. Jej różne wersje były ostatnio podtrzymywane przez Wundta, Durkheima, McDougalla, podobnie jak przez Junga.

S. Freud, Psychologia zbiorowości i analiza ,ja”, s. 71.

Zgodnie z opisem Bernheima: „Świadomie czy nieświadomie, sugestia była stosowana wśród wszystkich ludzi przez kapłanów, szarlatanów i magów. Ogólnie rzecz biorąc, sugestia zdominowała całą historię ludzkości. Odkąd grzech pierworodny był owocem sugestii węża wobec Ewy oraz Ewy wobec Adama, dopóki wybuchają wielkie wojny prowokowane przez religijny i polityczny fanatyzm, dopóki mamy do czynienia z krwawymi koszmarami Rewolucji i komunizmu, dopóty siła sugestii ma znaczenie". Bernheim zaproponował zatem nowy klucz do zrozumienia polityki, a zwłaszcza tych wydarzeń historycznych, w czasie których „łatwość ulegania sugestii” przez masy jest wykorzystywana przez nowych kapłanów, szarlatanów, magów przeciwko ich poprzednikom. 
w ten sposób - formacją zbiorową utworzoną przez dwie osoby"19. Konkretne i wyraźne różnice, jak choćby to, że podmiot hipnotyczny zazwyczaj nie pamięta tego, co dzieje się w trakcie transu, podczas gdy tłum wszystko zapamiętuje, zostają pominięte na rzecz głębszych podobieństw. W zbiorowości, tak jak w związku hipnotycznym, Freud odnajduje „to samo pokorne poddaństwo, powolność, bezkrytyczność [...] ten sam zanik własnej inicjatywy" ${ }^{20}$.

Niemniej jednak instynktualna podatność na uleganie hipnotycznej sugestii wcale nie wyjaśnia polityki lepiej niż instynktowne „uległość” (McDougall) lub „posłuszeństwo” (lord Bryce), których zaspokojenie czyni człowieka szczęśliwym. Nie przyjmując tego typu hipotez, Freud zaczął skłaniać się ku innemu wyjaśnieniu - głębszej identyfikacji afektów społecznych $\mathrm{z}$ naturalnymi. Przemiana jednostki w cyfrę nie nastąpiła z powodu podatności na sugestię, „zjawiska pierwotnego, nie poddającego się już dalszej redukcji" ${ }^{21}$, jak opisywał ją Bernheim, lecz była następstwem dużo bardziej zawoalowanej i specyficznej siły miłości. Jeśli jedność wyraża zasadniczą tajemnicę społeczeństwa politycznego, to znaczy fakt, że „zbiorowość najwyraźniej spaja jakaś siła”, to ,jakiejż [...] sile można by przypisać to dokonanie, jeśli nie Erosowi, który jest zwornikiem wszystkiego w świecie ${ }^{p 22}$ ? Oczywiście Freud znał inne, przejmujące odpowiedzi na to pytanie, włącznie z opinią Trazymacha mówiącego, że to wspólnota interesów jest podstawą jedności społecznej. Jednak argumentując wyłącznie z punktu interesu i wzajemnych korzyści traktujemy sprawę „w sposób aż nazbyt racjonalny” i zakładamy, że spójność społeczna nie trwa dłużej niż „bezpośrednie korzyści ze współpracy z drugim" ${ }^{23}$, co nie jest prawdą. Niezależnie od poprawności wyjaśnienia mówiącego, że ,istnieją więzi libidalne charakteryzujące zbiorowośćc ${ }^{24}$, nie ma wątpliwości, że uwzględnia ono niedostatki innych objaśnień jedności społecznej opartych na prymacie korzyści ekonomicznych i politycznych. Uzasadnienie psychologiczne Freuda staje się więc wyjątkowo wpływowe w ramach postmarksistowskich nauk społecznych.

Więzy libidalne są zatem silniejsze od korzyści, ale są także bardziej uciążliwe. Libido dostarcza społeczeństwu środki prowadzące do jedności, lecz nie dostarcza żadnego kryterium, przy pomocy którego można by ową jedność ocenić. Zakładając wyższość więzi libidalnej, Freud uczynił jedność celem samym w sobie. Wszystkie związki społeczne, do których należą lu-

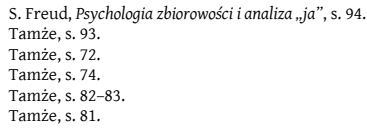


dzie, poczynając od rodziny, na ludzkości kończąc, są jednoczone przez miłość. Uzależnienie od miłości było dla Freuda tak powszechne, że zajął się nim nie tylko, by wyjaśniać postępowanie jednostek, lecz „w uzasadnionej nadziei, że odkryjemy w nich stosunki, jakie będziemy mogli przenieść na więzi występujące w zbiorowościach" ${ }^{25}$. W tym nowym rozumieniu stan posłuszeństwa ma charakter erotyczny. Jeśli rzeczywiście rodzimy się wolni, to tylko dlatego, że rodzimy się doskonałymi egoistami. Jeśli rzeczywiście zakuwamy się w łańcuchy, to być może czynimy to, „by być raczej w zgodzie z innymi niż w opozycji do innych, a zatem być może «z miłości do nich»"

W przedstawionym, wyraźnie dwuznacznym obrazie miłości odbija się więc Freudowskie zaniepokojenie polityką. By móc odnaleźć zależność libidalną w samym sercu towarzyskości, przed wejściem w szczegóły należy zinterpretować ją w najbardziej dwuznacznym rozumieniu. Rozumiana w szerokim sensie Freudowska idea libido jednocząca społeczeństwo obejmuje także impulsy seksualne, które są odwracane lub powstrzymywane, jak choćby więzi męskiego braterstwa. Z tego powodu miłość nie musi wydawać się złowieszczą siłą polityki. Teorię Freuda możemy nawet interpretować podobnie jak Fouriera, który roztoczył utopię społecznej współpracy osiąganej poprzez masową manipulację energią libidalną, zaprzęgnięcie przyjemności do pracy społecznej ${ }^{2 f}$. Wydaje się, że Freud w swych koncepcjach przyjął rozumienie „zdeseksualizowanego Erosa”, mówiąc o „popędach erotycznych [które] wydają się nam przecież tak w ogóle bardziej plastyczne, sterowne i zdolne do przesuwania niż popędy destrukcji" ${ }^{28}$. Pozytywna wersja politycznego erotyzmu pozostaje jednak nierozwinięta. W psychologii jednostki Freuda zakochanie rysuje się w ciemniejszych barwach, niż mogłoby to wynikać z krzepiących terminów takich jak „,towarzyskość”, , przywiązanie” czy do pewnego stopnia sama „miłość". Eros jest także zachłanny, sadystyczny oraz służalczo uległy. To druga, masochistyczna perspektywa, jaką Freud przypisuje uczuciom tłumu. Miłość, dzięki której stajemy się częścią społeczeństwa, uparcie prze do samounicestwienia, ,ja” roztapia się w grupie. Nie istnieje więc wiele przykładów polityki, będącej rozwinięciem idei miłości, przykładów miłości, która staje się polityczną siłą i której z łatwością poddają się rezultaty działań politycznych. Z punktu widzenia psychologii jedynie niewielki krok dzieli bycie zakochanym i zahipnotyzowanym. Myśl

\footnotetext{
Tamże, s. 84 .

Tamże, s. 74.

Utopijna socjalistyczna interpretacja Freuda została wyłożona w: H. Marcuse, Eros i cywilizacja, przeł. H. Jankowska, A. Pawelski, Warszawa 1998.

S. Freud, , Ja" $i$,to", [w:] tenże, Psychologia nieświadomości, przeł. R. Reszke, Warszawa 2009, s. 249 .
} 
Freuda jest więc bardziej wiarygodna jako „objaśnienie stanu zakochania przez hipnozę niż na odwrót" ${ }^{29}$.

Wyjaśnienia spójności społecznej dane nam przez Freuda i przez jego poprzedników w ramach psychologii społecznej mają podobną wadę: znacznie przeszacowują wspólnotowość grupy. Wyjaśnienie twórcy psychoanalizy ma jednak nad nimi jedną godną uwagi przewagę. Kryje się ona w nacisku, jaki kładzie on na skrytość przymusu, określającego relację polityczną, związek pomiędzy rządzącym i rządzonym. Przekonanie Freuda, mówiące, że polityka jest oparta na grupowej relacji erotycznej skierowanej ku władzy, precyzuje się dzięki twierdzeniu, że autorytet władzy jest zawsze spersonifikowany. Społeczeństwa polityczne charakteryzują się więc zdolnością skupienia autorytetu. Tak jak istnienie hordy domaga się istnienia wodza, zahipnotyzowany obecności hipnotyzera, a miłość „przedmiotu” - w ten sam sposób zbiorowość potrzebuje przywódcy ${ }^{30}$. Wzajemne więzi łączące członków zbiorowości znikają, jak utrzymuje Freud, ,wraz z zerwaniem więzi z dowódcą" ${ }^{31}$.

Freudowski obraz przywódcy pojawia się po raz pierwszy w Totemie i tabu w osobie prześladującego ojca hordy. Pierwszy władca był doskonałym egoistą, który kochał tylko siebie. Tylko przyjmując wyobrażenie „przemożnej i niebezpiecznej osobowości, wobec której można było jedynie zająć postawę biernie-masochistyczną, na rzecz której człowiek tracił własną wolę", Freud mógł wyobrazić sobie „stosunek indywiduum należącego do hordy pierwotnej do ojca pierwotnego" ${ }^{32}$. Nawet wówczas, gdy rysuje on obraz odmienny od Darwinowskiego mitu hordy, przekształcając osobę pierwotnego ojca w hipnotyzera, cechy tejże postaci pozostają te same. Freud uczy nas, że przywództwo jest ryzykownym kompromisem, który zawiera każdy człowiek. Pierwszą cechą prawdziwego przywódcy jest zachowywanie odrębności wobec tych, którym przewodzi, a jednocześnie niszczenie ich woli pozostawania odrębnymi nawzajem.

Tak niepochlebny obraz przywódcy pod pewnymi względami znajduje ponure potwierdzenie w niedawnej rzeczywistości politycznej. Funkcjono-

S. Freud, Psychologia zbiorowości i analiza ,ja", s. 94.

W wartościowym porównaniu działania masowego do mimowolnych czynów zahipnotyzowanego obiektu Freud zarzucił Le Bonowi i innym podobnym myślicielom ignorowanie najważniejszej rzeczy, która musi się pojawić - „to znaczy osoby, która zbiorowości zastępuje hipnotyzera". Tamże, s. 59. Z tego samego powodu Freud odrzucił tezę Wilfreda Trottera sformułowaną w pracy Instincts of the Herd in Peace and War (1916), mówiącą że człowiek jest „zwierzęciem stadnym”, ponieważ Trotter „nie zostawia dla wodza żadnego miejsca”. Tamże, s. 99. Człowiek jest raczej „zwierzęciem żyjącym w hordzie, jest on indywiduum należącym do hordy, której przywodzi jeden wódz". Tamże, s. 100.

Tamże, s. 79.

Tamże, s. 105. 
wanie nowożytnych monarchów i dyktatorów, jeśli nie wszystkich przywódców, potwierdza przekonania Freuda. Niezależnie od zdolności i siły monarchy lub przywódcy mas współczesna polityka jest potwierdzeniem funkcji psychologicznej, jaką sprawuje. Stanowi centrum, wokół którego organizują się inne poruszone istnienia. Freud wskazuje wprost na negatywną stronę tego stanu rzeczy. Rozluźnienie więzi libidalnych, łączących członków grupy z przywódcą, a w konsekwencji ich nawzajem, pozostawia jednostki w poczuciu izolacji i niepewności, co powoduje paniczny rozpad zbiorowości. Wyizolowane jednostki mogą zareagować na utratę uczestnictwa w zbiorowości próbą ponownego zawiązania grupy, która obala hierachię ról w celu odnowienia własnych tożsamości. Historie młodocianych gangów ulicznych w Ameryce oraz totalitarnych ruchów politycznych w Europie ilustrują proces zbiorowej paniki i nieuniknionego przyjmowania nowych tożsamości. Kryzys tożsamości nastąpił w całym świecie zachodnim, zaś związany z nim silny kryzys autorytetu znalazł odzwierciedlenie w każdym przedsięwzięciu terapeutycznym.

W przyjętych koncepcjach socjologicznych charyzmatyczny ojciecprzywódca zostaje zastąpiony przez organizację biurokratyczną. Freud utrzymuje natomiast, że ojciec-przywódca nigdy nie został tak naprawdę obalony przez swoich zwolenników, „synów”. Organizacja biurokratyczna musi być bowiem w pewnym sensie ucieleśnieniem postaci ojców założycieli, by mogła być efektywna. Pogląd ten wydaje się dzisiaj zyskiwać na wiarygodności. Możliwe, że zakończyło się już liberalne bezkrólewie, a rozpoczęła nowa epoka hipnotyzującego, prześladującego ojca, postaci całkiem przystającej do monstrualnej biurokracji, funkcjonującej po prostu jako rozwinięcie jej ,ja”. Faszyzm i stalinizm w pewnej mierze mogą służyc za ilustrację takiego stanu rzeczy. Odwołując się do wielkiej mitografii Georga Orwella: powieść Rok 1984 powinna być interpretowana jako opowieść o doskonałym wcieleniu w system polityczny hipnotyzującego i prześladującego ojca. „Kocham Wielkiego Brata" to istny slogan erotycznej uległości. Dorównuje on finałowemu, poniżającemu rozkazowi „,pocałuj mnie”, wydanemu przez Cipollę człowiekowi masowemu, jakim jest Mario, w powieści Mario i czarodziej Tomasza Manna, będącej wymyślną freudowską alegorią nowoczesnej polityki. Freud odnajduje w każdej polityce pewną dozę szaleństwa, należy jednak pamiętać, że stany zakochania są nie tylko podobne do hipnozy, lecz "w sferze tego, co normalne, są wzorem psychoz ${ }^{, 33}$. Führer w tej romantycznej psychologii może być więc pojmowany jako uwodziciel. Obraz uwodziciela jako najczystszego typu kochanka, nakreślony przez Kierkegaarda, jest

33 S. Freud, Totem i tabu, s. 318. 
wyrazem tego samego ducha, co spostrzeżenie Freuda, mówiące o miłości jako fundamencie państwa. „Bezkrytyczność miłości” staje się w skrajnej i nieprzyjaznej ocenie Freuda ",prapierwotnym źródłem autorytetu" ${ }^{34}$.

Całkowicie potępiając politykę, opisywaną na podobieństwo dzisiejszych totalitaryzmów, Freud przerysowuje bezpośredniość władzy. Polityka nie jest wiecznym masowym wiecem, z zafascynowanym erotycznie tłumem podatnym na każdy demagogiczny rozkaz. Polaryzujący umysł Freuda w polityce dostrzega jedynie jej masowy wymiar, politykę miłości lub nienawiści. Ulega więc rozpaczy wszystkich psychologów politycznych, włącznie z socjalistami takimi jak Silone, który w The School for Dictators podkreślał infantylność mas oraz ich ślepą łatwowierność, podatność na najbardziej prymitywne apele. Pewne cechy psychologiczne pojawiają się we wszystkich sytuacjach, gdy tłum staje się widzem, a politycy rozrywką, niezależnie od kształtu przekazywanych treści. Owa tyraniczna demokracja emocji jest dla Freuda modelem polityki.

W istocie każda polityka ostatecznie zawiera jakiś element tych groźnych emocji, pomimo że koncepcja ta w większej mierze odnosi się do triumfalnych pochodów, aniżeli nasiadówek politycznych. Korespondencja psychologii Freuda z pewnym typem współczesnej polityki, sprawia że nie jest ona współmierna z innymi. Nie wyjaśnia ona emocji stojących za polityką skostniałą, zajmującą się drobnymi przetargami politycznymi, w której administrowanie i zarządzanie ciągle jest ważniejsze jako model działania politycznego niż spotkania masowe. Psychologia zespołów komitetów politycznych może być bliższa sednu polityki niż psychologia mas. Polityka to nie tylko wielkie demonstracje, na których objawia się osobisty magnetyzm aktora. To także mniejsze spotkania, na których mniej entuzjastycznie podejmuje się dużo bardziej znaczące decyzje. Freud przypisuje życiu politycznemu rzadko występującą fatalność, której przeczą konflikty o przywództwo w nim obecne. Nawet w ramach polityki, w której publiczność zostaje uwiedziona czarem magika, pozostaje miejsce dla kramarzy, wszechobecnej agitacji i techników kierujących snop światła na główną atrakcję wieczoru. W technologicznym społeczeństwie masowym promocji wymaga nawet przywódca roztaczający wokół siebie erotyczny czar. Publiczność uczestnicząca we współczesnych spektaklach władzy już na wejściu chce łupów, zanim pozwoli rozniecić w sobie entuzjazm. Freud przeoczył rolę apatii, która może być oceniania pozytywnie jako przeciwieństwo „panicznego lęku” w ramach psychologii poskromionych aktorów sceny politycznej. Nie uznał

Tenże, Życie seksualne, przeł. R. Reszke, Warszawa 1999, s. 46. 
także obecności jakichkolwiek neutralistycznych emocji ani w sferze publicznej, ani w życiu prywatnym.

\section{III}

Freudowskie wyolbrzymienie siły przywódców, dokonane w Totemie i tabu i Psychologii zbiorowości i analizie ,ja”, przedstawia karykaturę władzy politycznej. W przypadku pierwotnego ojca Freud mówi: „Na początku dziejów człowieka był on «nadczłowiekiem», którego nadejścia Nietzsche spodziewał się dopiero w przyszłości. Jeszcze dzisiaj indywidua zbiorowe potrzebują złudzenia, że wódz sprawiedliwie i jednakowo obdziela ich miłością, ale sam wódz nie musi nikogo kochać, wolno mu mieć naturę pana, może być absolutnie narcystyczny, lecz musi być pewny siebie i samodzielny" ${ }^{35}$.

Freud niezmiennie wyobraża sobie przywódcę, zarówno prześladującego (pierwotny ojciec, Bóg), jak i prześladowanego (pierwotny brat, Mojżesz czy Chrystus), jako człowieka pewnego siebie. Osoba ta była „w niewielkim stopniu skrępowana libidalnie”, a jej wola „nie wymagała wzmocnienia przez wolę innych" ${ }^{36}$, w odróżnieniu od słabych intelektów i skolektywizowanych pragnień zwolenników. Twórca psychoanalizy, nie poświęcając więcej uwagi psychologii przywódców, ich twórczy urok uznaje za pewnik. Usiłując odkryć uwarunkowania jedności zbiorowej, dość fałszywie interpretuje życie polityczne, bez różnicowania jego odmiennych wcieleń. Postrzega je w całości jako podległe zaklęciom władzy.

To abstrakcyjne, nazbyt formalne nastawienie ma tendencję do przerysowywania elementu niezmienności władzy politycznej. Psychologia Freuda odznacza się wyraźnie konserwatywnymi następstwami: w historii nic jakościowo nowego się nie zdarza. Przywódca jest niezmiennie przymuszany do odgrywania roli ojca, gdyż jego zwolennicy są dziećmi. Polityka staje się więc ciągłym i niezmiennym zmaganiem pomiędzy pokoleniami. Psychologiczne wahadło ambiwalencji sprawia, że zmiana społeczna staje się powtarzalna; relacje społeczne są zaś interpretowane przez pryzmat niezmiennych psychologicznych potrzeb, które zaspokajają. Protest społeczny zostaje pozbawiony niemal całkowicie wartości jako kolejna manifestacja ambiwalencji uczuć. Szacunek i sympatia wobec uprzywilejowanych zderza się z nieświadomymi uczuciami wrogości. Powszechnie żywiona „nieufność” wobec władców jest również „przejawem tej samej nieświadomej wrogości”, a nie wynikiem racjonalnej oceny niepowodzeń i błędów rządzących. W konsekwencji żaden władca nie ma władzy absolutnej, wyjąwszy złudzenia jego

Tenże, Psychologia zbiorowości..., s. 102.

Tamże. 
zwolenników. Sprawiedliwość i prawość zostają poddane patologii uległości. Zarówno w przypadku paranoi, jak i w polityce „polega to na tym, że określonej osobie przypisuje się niezwykle duże znaczenie i nieprawdopodobną wręcz wszechmoc" ${ }^{\text {,37 }}$. Dzięki psychologii libidalnego uczestnictwa Freud kładzie podwaliny pod swoją genetyczną interpretację władzy.

Jeśli jednak rozważyć inne elementy jego teorii, okazuje się, że władza nie otrzymuje u Freuda pełnej legitymizacji. Doktryny autorytaryzmu generalnie uświęcaja proces społeczny, Freud zaś go kwestionuje. Jego psychologia społeczna jest także krytyką autorytetu, częściowo dlatego, że pojmuje on politykę w nieuchronnie autorytarny sposób. Całościowe obnażenie mocy wszystkich autorytarnych wzorów władzy staje się celem psychoanalizy.

Monumentalny Freudowski obraz ojca jako wzoru władzy jest bezpośrednio połączony z przekonaniem, że każda jej forma przechodzi obecnie kryzys. Freud ubolewał nad psychologicznym marazmem wynikającym z faktu, że wszyscy silni przywódcy nie są już darzeni szacunkiem ${ }^{38}$. W ten sposób, jednocześnie przyczyniając się do kryzysu, sam jako jeden z pierwszych zaczął bić na alarm. Psychoanaliza postrzega ojca jako problem bądź co bądź podstawowy, opowiadając się za przyjęciem zdystansowanego, jeśli nie wrogiego, nastawienia do autorytetu oraz wzmacniając jego kryzys nowym językiem i racjonalizacją. Wraz z obaleniem prawowitości władzy dokonanym przez współczesne nauki społeczne oraz obnażeniem „interesów”, leżących u podstaw instytucji i urzędów społecznych, samo pojęcie prawowitości staje się wątpliwe. Freud nadaje tym wątpliwościom dodatkowy psychologiczny połysk.

Siły stojące za burzycielskim impetem teorii Freuda biorą się z użycia przez niego rodziny i innych modeli genetycznych. Freud mniemał, że wszystkie uczucia rodzą się w sferze prywatnej, lecz zostają zracjonalizowane i skierowane na zewnątrz ${ }^{39}$. Polityka może zatem zostać sprowadzona do jednostki i łańcucha projekcji, który od niej bierze swój początek. Cześć

${ }^{37}$ Tenże, Totem i tabu, s. 286. Freud zauważa, że „rezultaty [...] konfliktu” pomiędzy wrogością a czcią „wykazują [...] taką różnorodność”, iż relacja między rządzącymi a rządzonymi może być doprowadzona do sytuacji „ambiwalentnej postawy uczuciowej”.

Tenże, Kultura jako źródło cierpień, [w:] tenże, Pisma..., s. 226.

Freudowska idea mówiąca, że treści uczuć publicznych to tak naprawdę „przeobrażone” afekty prywatne, pojawia się już w 1896 roku: „Afekt wyrzutu może przy pomocy pewnego psychicznego wzmocnienia przeobrazić się w każdy inny przykry afekt. Kiedy tak się staje, nic już nie przeszkadza zamienionemu afektowi, by stać się świadomym. Dlatego też samooskarżenie (o dokonanie czynu seksualngo w dzieciństwie) może się łatwo przekształcić we wstyd (by nikt nie mógł o tym się dowiedzieć), hipochondryczne napięcie (by pewne urazy fizyczne były rezultatem działania, które wywołało samooskarżenie), lęk przed wspólnota (strach przed karą wymierzoną przez świat za odstępstwo), napięcie religijne". Zob. tenże, The Defence Neuro-Psychoses, [w:] tenże, Collected Papers of Sigmund Freud, t. I, red. E. Jones, J. Strachey, London 1949, s. 165. 
i przesadny szacunek, jakimi zostaje otoczony rządzący, to jeden z wielu efektów „stosunku dziecka do ojca" ${ }^{40}$. Poprzez podporządkowanie polityki nie tylko psychologii, lecz wręcz (używając sformułowania Spencera) psychologii instytucji rodzinnych Freud ujawnia swą antypolityczną stronniczość.

Porównanie rodziców i rządzących dokonane przez Freuda nie wnosi nic nowego w stosunku do podobnych analogii obecnych już od czasów antycznych. Bentham pisał, że dziecko rodzi się „w stanie idealnej społeczności politycznej, gdzie szanuje swoich rodziców", i dlatego też może potem, „wchodząc w nowe społeczności, włączać się w życie kolejnych społeczności politycznych, mniej lub bardziej doskonałych". Opis ten jest niemal identyczny z Freudowskim porównaniem władcy do „obrazu ojca”. W przeciwieństwie jednak do Benthama zamiary Freuda nie są jedynie opisowe, lecz także krytyczne. Freud nie koncentruje się na osobie ojca, lecz raczej na sposobie, w jaki określony model rodzicielski trwa i utrzymuje wpływ na zachowania publiczne. Jakakolwiek zmiana porządku społecznego staje się przyswajalna jedynie w obrębie naturalnego sposobu działania rządu, rodziny. Uczucie patriotyzmu może więc zostać zdemaskowane jako próba rozwiązania rywalizacji rodzeństwa, zaś cele rewolucji mogą zostać sparodiowane jako uwsteczniające nieposłuszeństwo.

Taki opis polityki jest bardzo atrakcyjny dla klas wykształconych na Zachodzie, zmęczonych łamaniem zasady szczerości w życiu politycznym. Analogie między życiem prywatnym a sferą publiczną służą podważeniu wszelkiego oddania życiu publicznemu. W przypadku rządzonych Freud zastosował znane porównanie pomiędzy masami a dziećmi; uczucia polityczne wywodzą się zatem z synowskiego oddania. Osobowość polityczna rządzonych jest wzburzana przez niezaspokojone pragnienia przywiązania (czy szacunku), które zostały podkreślone i niezaspokojone w relacjach osobistych. Osobowość polityczna powstaje wobec tego w wyniku magicznej sztuczki. Osobiste pragnienia są jedynie „przesuwane” na ciało polityczne.

Polityka przestaje być płomienna, kiedy człowiek psychologiczny odkrywa, jak symptomatyczne jest jego działanie. Zwolennicy władzy tracą swoją żarliwość, kiedy znajdują w swych przywódcach obraz ojca. Wyznawca traci swoją wiarę, kiedy widzi, że ukrywają się w niej wyparte uczucia. „Przesunięcie” (displaced) niemal nie różni się od „zgubienia” (misplaced). Freud żywił potężne racjonalistyczne podejrzenia dotyczące entuzjazmu, więc jego psychologia ujawnia swego antyradykalnego ducha poprzez dyskredytację namiętności w ogóle.

Tenże, Totem itabu, s. 286. 
Psychoanaliza jest więc podstawą współczesnej podejrzliwości wobec polityki, zarówno w przypadku patologii, będących udziałem przywódców, jak i ich zwolenników. We wczesnych pracach Freuda często pojawia się myśl, że człowiek władzy jest neurotykiem ${ }^{41}$. A jednak dążenie do władzy nie musi być reakcją na bezsilność, może świadczyć o zdrowej identyfikacji z jej autorytetem. Kariera polityczna Tafta Juniora czy Roosevelta może być postrzegana równie dobrze jako wynik „przedarcia się” czy „uzewnętrznienia identyfikacji” z ojcem i „fiksacji” na jego punkcie. Nawet w przypadku, gdy identyfikacja z ojcem jest pierwotną motywacją określonych działań, zwykle motywacje te dojrzewają i oddalają się od swych dziecięcych źródeł. Jeśli ograniczymy twierdzenie Freuda mówiące, że kryterium ważności motywacji jest to, jak głęboko jest ono zakorzeniona w przeszłości, możemy usunąć niemal wszystkie genetyczne podejrzenia dotyczące przywództwa politycznego, które przenikają współczesne teorie z obszaru psychologii politycznej ${ }^{42}$.

Psychoanaliza stosowana nie traci nic ze swojej wartości, jeśli odejść od skupienia się na neurotycznym aspekcie przywództwa. Koncepcja ta, powracająca zarówno w bezpośrednich twierdzeniach, jak i terapeutycznych implikacjach, nie ma nic wspólnego z postrzeganiem przywódcy politycznego jako osoby chorej, wiąże się z badaniem patologicznego stanu jego zwolenników. Nie Hitler, lecz Niemcy, nie Mussolini, lecz Włosi mogliby zostać przedmiotem analizy psychologii politycznej. Pesymizm, bijący z tego typu analiz, jest wyraźnie widoczny w dziełach inspirowanych freudyzmem, takich jak choćby Osobowość autorytarna. Psychologia głębi zniszczyła optymistyczną wiarę demokratów w racjonalność ludzi wolnych poprzez odkrycie, że przeciętny obywatel (w tłumie lub poza nim) nie jest racjonalny. Nie jest to jednak powód do rozpaczy. Wciąż bowiem u Freuda pozostaje to, co jest dla niego inną, najwyższą formą racjonalności: wiedza o irracjonalnym, wiedza, która może być używana homeopatycznie, by podejmować przemyślane decyzje, kluczowe dla demokracji. Najlepiej byłoby, gdyby elektorat demokratyczny „w wolnym społeczeństwie wybierał przywódców i lekarzy”, gdyż „problem przywódcy demokratycznego... jest równoznaczny z rozwojem zdrowia społecznego, a nie choroby" ${ }^{43}$. W przytoczonej wypowiedzi Harolda Lasswella jednoznacznie objawia się leczniczy charakter współczesnego liberalizmu.

${ }^{41} \quad$ Klasycznym przykładem tego zjawiska jest, wspomniany wcześniej, Szekspirowski Ryszard III. Jeśli chodzi o inne przypadki, zob. H. Sachs, Caligula (1924).

42 Zob. przykładowo prace Harolda Lasswella. H. D. Lasswell, Psychopathology and Politics, Chicago 1930; tenże, Power and Personality, New York 1948.

43 Tenże, Power and Personality, New York 1948, s. 146. 
Problem demokratycznego przywództwa nie może jednak zostać rozwiązany tak łatwo. Poprzez uciekanie się do technokracji psychiatrów społecznych, którzy użyją kreskówek, filmów, telewizji, a nawet, jeśli to konieczne, „środków narkotycznych i hipnotycznych, by obniżyć ogólne napięcie w społeczeństwie" ${ }^{44}$, kultura demokratyczna może się rozpuścić w stanie uległości władzy, z którego może już nie wyjść. Liberalizm oparty na możliwości racjonalnego edukowania dostarczył składników niezbędnych do sporządzenia Freudowskiej mikstury. Nie ma jednak żadnego powodu, dla którego związana z państwem kadra psychiatryczna miałaby służyć celom demokratycznym. Twierdzenie Lasswella: „dzisiaj jesteśmy... świadomi, iż zbyt wiele nacisku zostało położone na dialektykę i potrzeba uzupełnić ją innymi sposobami mówienia i myślenia" ${ }^{45}$ - prześlizguje się nad faktem, że owe inne sposoby są najzupełniej irracjonalne, a w społeczeństwie masowym bardziej podatne na manipulację niż kiedykolwiek wcześniej. Obywatelepacjenci mogą zostać przekonani, że ich zarzuty dotyczące danego reżimu są ugruntowane w czysto prywatnych problemach. Psychiatra stara się wyjaśniać żółnierzowi na froncie, że jego niechęć do zabijania nie ma nic wspólnego z obiektywnymi okolicznościami wojny, które dla większości z jego kolegów są możliwe do przetrwania. Przekonanie obywatela-pacjenta, że jego niepokój ma subiektywne źródła, może powstrzymać go od zadawania kłopotliwych pytań o obiektywną ocenę sytuacji politycznej. Lekarze moralności w obecnym porządku społecznym osiągnęli sukces, który stał się substytutem honorów. Ich społeczna przydatność ma objawiać się w sukcesach odnoszonych przy pomocy zwięzłych, dziarskich wyjaśnień, w zapobieganiu, wariowaniu żołnierzy na liniach frontu. Mimo wszystko, widząc obraz protestującego żołnierza i zaklinającego jego lęki psychiatry, trudno oprzeć się wrażeniu, że teorie psychologiczne nie służą w żaden sposób racjom wyższym niż państwowe. Skoro działanie społeczne jest pojmowane jako wynik uwolnienia się od osobistych odczuć, to protest społeczny może być wyjaśniany jako symptom neurozy. Psychiatra może więc odgrywać znaczącą rolę w strukturze ideologii autorytarnej, promując obraz społeczeństwa jako szpitala. Chore społeczeństwo, którego obywateli-pacjentów należy wyleczyć, to jedno z najbardziej subtelnych wyobrażeń autorytarnych.

Psychologia niemal w osamotnieniu wspiera rozwój poczucia politycznego wycofania. Prowokowanie apatii społecznej w tak wyrachowany sposób wyraża odrazę do naiwnego dzielenia zachowań społecznych na właściwe i błędne. Konflikty o dobro zostały zdiagnozowane na nowo jako awan-

Tamże, s. 200.

Tamże, s. 197. 
tury o wartości. Prawda stała się tylko teorią, wyraźnym uzasadnieniem dla reakcji praktycznej, która wyrasta z głębszych źródeł.

Prorocy politycznego wycofania przypominają proroków zaangażowania ostatecznego. Zarówno Freud, jak i Marks poszukują defektów w porządku społecznym, by móc odkryć coś poza nim - Marks porządek ekonomiczny, Freud psychologiczny ${ }^{46}$. Dla obu to, co polityczne, jest zjawiskiem drugorzędnym, podlegającym ostatecznie stosunkowo prostej analizie. Psychoanaliza jest zagrożona śmiertelnym niebezpieczeństwem przeformalizowania. Poszukując podstawowej motywacji wojny, psychologia odnajduje różnorodne rodzaje agresji, co niezbyt przystaje do historii dyplomacji czy interesów strategicznych. Freud zupełnie zdyskredytował „interes” jako jednostkę analizy, w zamian preferując „motywację”. Badając funkcje władzy instytucjonalnej, psychologia przywraca klasyczne porównanie państwa do rodziny, co w niewielkim stopniu pozwala rozróżnić obecnie w nich przekonania i dążenia. Wszystko to traci swoją ostrość w ramach zaciemniającej analizy motywacji.

Freudyzm dodał oczywiście nowy wymiar do sprzeciwu nauk społecznych wymierzonego w pytania o prawdę i fałsz. Marks powiedziałby, że ludzie zmieniają swą przynależność polityczną nie tylko dlatego, że w ich myśleniu dochodzi do zmiany, a swe dotychczasowe poglądy zaczynają uważać za błędne, lecz również dlatego, że mimowolnie podpierają swe pozycje klasowe. Freud zaś przekonywałby, że preferencje polityczne nie są skutkiem racjonalnych spostrzeżeń, lecz efektem przywiązania do politycznych ojców - Lenina, Roosevelta, Hitlera. Obraz ojca przypieczętowuje moralny charakter jego zwolenników, tak jak Mojżesz (ulubiony przykład Freuda) ukształtował charakter Żydów, zaś Lenin charakter bolszewików ${ }^{47}$. Różnice nie dzielą tu zasad, lecz tylko konkurujących politycznych identyfikacji. Począwszy od nauk politycznych Lasswella do wulgaryzacji teorii Freuda u Koestlera w jego antypolitycznej noweli Arrival and Departure, sprawy publiczne stały się jedynie udramatyzowanymi sprawami prywatnymi.

Najbardziej wymowny przykład wspomnianej redukcji tego, co polityczne, to podejście do entuzjazmu rewolucyjnego jako cechy strukturalnej charakteru neurotycznego. Wyjątkowo przychylne przyjęcie psychoanalizy w Ameryce wynikało z dyskredytacji politycznego radykalizmu, postrzega-

${ }^{46}$ Spójrzmy przykładowo na próby wyjaśnienia uprzedzeń rasowych. Marksiści identyfikują uprzedzenie rasowe jako próbę wytłumaczenia wyzysku ekonomicznego. Freudyści interpretują to samo jako przeniesienie niemożliwych do zaakceptowania dążeń wewnętrznych na mniejszość. Obie strony próbują wyjść poza samo zjawisko i w ten sposób je wytłumaczyć.

47 Teza ta została rozwinięta przez freudowskiego psychologa polityki Nathana Leitesa. Zob. N. Leites, A Study of Bolshevism, Glencoe 1953. 
nia rewolucjonisty jako szczególnego rodzaju neurotyka, który swą agresję przenosi w sferę publiczną. Freud proponuje więc znakomity sposób redukcji charakteru rewolucyjnego, sprowadzając go zasadniczo do buntu przeciwko „ojcu” ${ }^{48}$. W związku z tym rewolucyjne ideologie, zarówno lewicowe, jak i prawicowe, mogą być traktowane jako następstwa konfliktów edypalnych. Weźmy choćby równanie Lasswella, służące do badania polityki: $\mathrm{p}\{\mathrm{d}\{\mathrm{r}=\mathrm{P}$. Człowiek polityczny (P) jest wyrazem „przeniesienia” (d) i „racjonalizacji” (r) motywacji prywatnych $(\mathrm{p})^{49}$. Ostatecznie sfera publiczna ma charakter psychologiczny To, co publiczne czy społeczne, jest tylko „uzewnętrznieniem treści” wewnętrznych. „Treść utajona” to wynik psychologicznego mechanizmu, opartego na ukryciu jej przez treść oczywistą. Teoria socjopsychologiczna opiera się więc otwarcie na tłumaczeniu tego, co publiczne, przez pryzmat tego, co prywatne. Z punktu widzenia psychoanalizy postacie św. Pawła, Leonarda da Vinci czy Hitlera nie są w pełni czytelne w swych rolach publicznych - proroka, artysty, polityka. W tym właśnie zawierają się atrakcyjność i dwuznaczność zdominowania nauk społecznych przez psychoanalizę. Z powodu ostrości i wszechobecności życia publicznego, człowiek współczesny ma możliwość nieustannego odnoszenia się do sfery publicznej, poszukiwania tych doktryn, które są intelektualnymi odpowiednikami interesów prywatnych. Freudyzm wyznacza więc kierunek, prowadzący ku nowej duchowości, dalekiej od świata społecznego, który twórca psychoanalizy postrzega zawsze w odcieniach szarości.

\section{IV}

Jako lekarz i powiernik człowieka w jego egoistycznych pragnieniach i marzeniach Freud ukrycie akceptuje represyjność społeczeństwa. Sugerując części społeczeństwa mniej wrogie nastawienie do instynktów, zakłada, że interesy jednostki i społeczeństwa nie są zgodne. Skupienie praw w rękach potężnych przywódców uważa za usprawiedliwione przez tendencje anarchiczne, słabość, pasywność i łatwowierność mas. Dopełnieniem jego zarzutów jest zaś odwołanie się do „lenistwa” mas. Pomimo że Freud w niewielkim stopniu odwołuje się otwarcie do leczniczej konieczności pracy, w pewien sposób ją zaleca, dyskredytując publiczne i prywatne mrzonki, obecne w marzeniach, neurotycznym wycofaniu czy etycznym utopizmie. W swoim najbardziej polemicznym eseju zatytułowanym Przyszłość pewnego złudzenia temat podejmuje jednak wyraźnie. Człowiek musi pracować. Freud w starym stylu krytykuje więc niedojrzałość i zależność niepracujących. Biorąc zaś pod

Zob. uwagi Freuda na temat Dostojewskiego w eseju Dostojewski i ojcobójstwo (1928).

H. D. Lasswell, The Psychopathology of Politics, [w:] tenże, The Political Writings of Harold D. Lasswell, Glencoe 1951, s. 75-76. 
uwagę fakt, że „ludzie nie są spontanicznie skorzy do pracy”, zaś „namiętności ludzkie nie są podatne na siłę argumentów”, mamy do czynienia z „dwoma szeroko rozpowszechnionymi cechami ludzkimi" ${ }^{, 0}$, które czynią pewną dozę przymusu społecznego nieuniknioną.

Mesjanistyczny ton prowadzi Freuda do podziwu dla zdecydowanych i bezwzględnych mniejszości. W Wykładach ze wstępu do psychoanalizy: nowym cyklu rysuje on obraz „ludzi czynu, niewzruszonych w swych przekonaniach, nieczułych na zwątpienie i niewrażliwych na cierpienia kogokolwiek, kto stanie im na drodze" ${ }^{\text {51 }}$. Pisząc do Einsteina, przedstawia z kolei obraz Platońskiego państwa, którego rządzący są „wspólnotą ludzi”, którzy osiągnęli swą drugą naturę i tak oto "swe życie popędowe poddali dyktaturze rozumu" ${ }^{\circ 2^{\circ}}$. Skoro masy w sposób naturalny nie doceniają tych, którzy stoją wyżej w hierarchii społecznej, to ich krnąbrność daje asumpt do rządzenia nimi w ich imieniu, co przybiera czasami bezwględną formę, jak w Rosji Radzieckiej. Freud wyraża ironiczny podziw dla bolszewickiej mniejszości, żelaznego człowieka, który podjął „wspaniałą próbę ustanowienia nowego porządku społecznego" "53. Pisząc to w 1927 roku, jest jednak jednocześnie przekonany, że bolszewicy poniosą klęskę, jak wszyscy przedpsychologiczni rewolucjoniści.

Nie chodzi o to, że Freud pochopnie odrzuca nadzieję na wolne i próżniacze społeczeństwo. Duże wrażenie wywarły na nim choćby poglądy jego wiedeńskiego kolegi, socjalisty Josefa Poppera-Lynkeusa. Przemówiła do niego próba wprowadzenia społeczeństwa w stan wolności, szczególnie (dostrzegał on uczciwy realizm w tym paradoksie) że same starania miały przyjąć formę represyjną, podobnie jak reformy w Rosji. Nadzieje utopijne mogą być podtrzymywane tylko dzięki znaczącym psychologicznym koncepcjom, człowiek jest wszakże wyposażony w najbardziej zróżnicowane instyktualne skłonności. Skoro natura ludzka jest plastyczna, czy możliwa jest zatem jej przemiana? Freud uważał, że nie. Eksperymenty takie jak socjalizm miały przezwyciężyć polityczne opresje poprzez zamianę jednej formy władzy publicznej na inną, zaś Freud utrzymywał niemal tautologiczne przekonanie, że zbiorowość we wszystkich swych dążeniach jest irracjonalna.

Zbiorowość jest w stanie dokonać większych rzeczy niż jednostki „w rodzaju aktów wyrzeczenia, altruizmu, poświęcenia się dla ideału” ${ }^{54}$. Nie rehabilituje to jednak wspólnoty w oczach Freuda, jej moralne osiągnięcia są

\footnotetext{
S. Freud, Przyszłość pewnego złudzenia, [w:] tenże, Pisma..., s. 125.

Tenże, New Introductory Lectures on Psycho-Analysis, London 1933, s. 231.

Tenże, Dlaczego wojna?, [w:] tenże, Pisma..., s. 238.

Tenże, New Introductory..., s. 231.

Tenże, Psychologia zbiorowości..., s. 61.
} 
możliwe tylko dlatego, że racjonalne moce człowieka zostają odpowiednio stłumione poprzez żar przynależności do grupy. Racjonalność z punktu widzenia psychologii społecznej powoduje rozpad życia grupowego. Freud szanuje więc ideał racjonalności w sferze prywatnej właśnie z uwagi na irracjonalność zakorzenioną w życiu zbiorowości.

Jeśli społeczeństwo jest utrzymywane w jedności dzięki irracjonalnemu szacunkowi i zależności od przywódcy, to dopóki pozostaje stabilne, dopóty zawsze jest w pewnym sensie autorytarne. Określone jako wspólnota nierównych, społeczeństwo naprawdę równych jednostek jest dla Freuda niemożliwe do wyobrażenia. Freudowska krytyka ideałów równościowych wydaje się bardziej oryginalna i mniej zmienna niż jego przebrzmiały strach przed gnuśnymi, infantylnymi masami. W ten sposób wychodzi on bowiem poza dziewiętnastowieczny liberalizm, psychologizując konwencjonalną, leseferystyczną krytykę społeczeństwa zaplanowanej równości. Brak uzupełnienia zasad i zaleceń egalitarystycznych przez skuteczne pomysły ekonomiczne został przełożony przez Freuda na niedostatek wystarczająco silnych motywacji libidalnych. Podkreśla on tutaj wartości wysiłku, obawiając się sytości emocjonalnej w wypadku, gdy bodziec niedostatku zostanie usunięty. Sugeruje tym samym, że bez erotycznej nierówności, niedostatku i w konsekwencji rywalizacji, sublimowanej częściowo dla pożytku społecznego, będzie nam brakować tych antagonizmów i skłonności, które podtrzymują wspólnotę. Argument to znany, tyle że przeniesiony na egzotyczny grunt. Zastąpienie zadowolenia ekonomicznego satysfakcją emocjonalną i psychologiczną wydaje się najnowszą wariacją przekształcającą ekonomię klasyczną $\mathrm{w}$ doktrynę moralną.

Rozumiejąc, że władza jest niezbędna, zaś w ramach zbiorowości muszą występować nierówności, Freud pozostaje umysłem liberalnym. Autor Totemu i tabu sprzeciwia się meliorystycznej wizji rozwoju społecznego, według której przymus sam w sobie jest tylko rezultatem wadliwej organizacji kulturowej, sprawiającej, że człowiek staje się mściwy i wrogi innym. Przekonanie, że pewne formy przymusu społecznego i kulturowego są niemożliwe do uniknięcia, nie jest poglądem kanonicznie liberalnym. Freud jednak neguje nie tylko liberalny, lecz także marksistowski i każdy inny ideał postępu społecznego, zalecając oswojenie się z władzą, a nie jej obalenie. Uznanie konieczności przymusu społecznego - w terminologii psychoanalitycznej, represji - nie pozwala widzieć w nim zwolennika jakiegolwiek systemu represyjnego. $\mathrm{W}$ istocie $\mathrm{w}$ swej anatomii rodzinnych modeli władzy i wewnętrznego przymusu, które łączą członków przypadkowych tłumów, kościołów, państw, w swych obrazach ojcobójczej winy, z której wynika posłuszeństwo - we wszystkich tych ideach etyczny ton nauki Freuda wydaje 
się sceptyczny. Autor Totemu i tabu pozostaje niewrażliwy na wizje wielkiej przemiany porządku politycznego.

Rodzinne wzory, którymi posługuje się Freud, skierowane są przeciwko autorytetowi. Porównując obywateli do dzieci, a przywódców do ojców, całkowicie niszczy nimb otaczający władzę polityczną. Analogia przyrównująca państwo do rodziny - oraz terapia mającą potencjalnie wyzwolić nas z jej niewoli - bezpośrednio kwestionuje fundament zaufania społecznego. „Od tego czasu”, pisze Freud, „musi jednostka ludzka poświęcić się wielkiemu zadaniu uwolnienia się od rodziców [...] Dla syna polega zadanie to na tym, by oderwać się od matki jako przedmiotu życzeń swego libido i zużytkować owe pragnienia do wyboru realnego obcego przedmiotu miłości, a dalej, by pojednać się z ojcem, jeśli trwa nadal we wrogim doń stosunku, lub też by uwolnić się spod presji z jego strony, jeśli jako reakcja na dziecięcy bunt nastąpiło poddanie się. Zadania te ma przed sobą każdy; jest godne uwagi, jak rzadko udaje się je wykonać w sposób idealny, to znaczy poprawny zarówno pod względem psychologicznym, jak i społecznym"

Aby stać się „członkiem społeczeństwa" ${ }^{\text {, }}$, na pozór jednostka winna uwolnić się spod władzy rodzicielskiej. Jednak w innym aspekcie wspomniana analogia nadal ma uzasadnienie. Skoro rząd potrzebuje zasobów synowskiego oddania, zaś wzrastająca władza rodzicielska przyczynia się do dobrostanu jednostki, to czy Freud daje miejsce rewolcie społecznej w normalnym biegu spraw ludzkich?

Jeśli Freud nie dokonałby rozróżnienia państwa i rodziny, skutki buntu przeciwko władzy rodzicielskiej byłyby równie szkodliwe dla państwa. Rozkwit społeczeństwa politycznego, przedstawiony w Totemie i tabu, następuje w dwóch etapach. Pierwszy etap to rząd hordy, rządy pierwotnego ojca, później zaś rządy rodzinne. Freud wyjaśnia, że organizacja państwa nie jest zwyczajnie wzorowana na rodzinie. Sama rodzina jest tak naprawdę oswojoną rekonstrukcją pierwotnej hordy ${ }^{57}$. Dlatego też Freud dostrzegał w polityce przede wszystkim odrodzenie się uczuć właściwych hordzie, prowadzących do pewnych ludzkich napięć pomiędzy dążeniami erotycznymi w ramach rodziny a potężniejszymi, bardziej prymitywnymi i kategorycznymi celami państwa. Pogląd przekonujący, że dla miłości seksualnej, „miłości do kobiety" nie ma miejsca wśród uczuć społecznych ${ }^{58}$, nie tylko illustruje jego kon-

Tenże, Wstęp do psychoanalizy, przeł. S. Kempnerówna, W. Zaniewicki, Warszawa 1992, s. 308-309.

Tamże, s. 309.

S. Freud, Psychologia zbiorowości..., s. 112.

Tamże, s. 116-117. Zob. zwłaszcza następujące fragmenty: „bezpośrednie dążenia seksualne są niekorzystne dla formacji zbiorowej. Co prawda i w historii ewolucji rodziny występowały takie związki zbiorowe oparte na miłości seksualnej (małżeństwo grupowe), ale im 
serwatyzm i mizoginię. Wskazuje on także na dwuznaczny obraz rodziny jako nie tylko modelu przynależności politycznej, lecz także pewnego ograniczenia, jakie na tę przynależność nakłada, uwypuklając antagonistyczne lojalności oraz fakt, że jest ona skarbnicą kapitału erotycznego.

Freud powiela wiele liberalnych stereotypów skierowanych przeciwko państwu. Jego obraz wojny jest szczególnie wyrazistą obawą liberałów. Skoro zachowania zbiorowe niezmiennie wywodzą się ze sfery nieświadomości, polityka jest dla zbiorowości niczym katharsis - podobnie jak sztuka dla jednostek. Wojny i rewolucje zrywają z postawami archaicznymi. Wojna „sprawia [...] że oto odpadają z nas warstwy naniesione przez późniejszy rozwój kultury, spod których wyłania się ukryty pod nimi praczłowiek" ${ }^{\text {,59 }}$. Polityka nie jest instrumentem realizacji racjonalnego interesu, tak jak dzieje się to według marksistów. Według Freuda, w jeszcze większym stopniu ignorującego idealistyczną retorykę polityków, narody posługują się „interesami gwoli zracjonalizowania namiętności; wysuwają swe interesy na plan pierwszy, aby móc uzasadnić zaspokojenie swych namiętności" ${ }^{\prime 60}$. Rozumowanie to zostaje zastosowane w Totemie i tabu jako źródło pierwotnego prawa. Freud odrzuca natomiast powierzchowne pojęcie prawa nakładanego „przez wodzów i kapłanów celem zabezpieczenia swych własności i przywilejów" ${ }^{\text {"11 }}$. Mnóstwo antropologicznych świadectw, mówiących o ambiwalentnym stosunku rządzących do prawa, dostarcza Freudowi dostatecznego dowodu na to, że ci, którzy stosują prawo, są także wystawieni na jego sankcje, co świadczy, że nie odbija ono jedynie ich interesów. Nawet interes trybalny czy narodowy jest nazbyt zindywidualizowaną i racjonalną motywacją dla działania zbiorowego. Interes własny jest w najlepszym razie konsekwencją głębszych motywacji charakteryzujących wszystkie społeczeństwa.

większego znaczenia nabierała miłość płciowa dla ,ja”, im silniejszy stan zakochania wytwarzała, tym bardziej natarczywie domagała się ograniczenia związku do dwóch osób una cum uno - wyznaczonego przez samą naturę celu genitalnego [...] Dwie osoby zdane na siebie $\mathrm{w}$ celu zaspokojenia genitalnego demonstrują przeciwko popędowi stadnemu, przeciwko uczuciu zbiorowemu, jako że poszukują samotności” (s. 116). I dalej: „W wielkich sztucznych zbiorowościach - w Kościele i armii - nie ma miejsca dla kobiety jako obiektu seksualnego. Miłosny związek między mężczyzną i kobietą pozostaje poza tymi organizacjami [...] Bezpośrednie dążenia seksualne zawierają także - nawet jeśli chodzi o indywidua rozmyte w zbiorowości - część aktywności indywidualnej. W sytuacji, gdy stają się one nadmiernie silne, doprowadzają do rozkładu każdej formacji zbiorowej. Kościół katolicki miał najlepsze powody po temu, by swym wiernym polecać bezżeństwo, a na swych kapłanów nakładać celibat, ale zakochanie często popychało nawet duchownych do wystąpienia z Kościoła. W ten sam sposób miłość do kobiety zrywa więzi zbiorowe w obrębie rasy, zróżnicowania wynikające z narodowości i społecznego porządku klasowego, tym samym zaś dokonuje dzieł ważnych dla kultury" (s. 117).

S. Freud, Aktualne uwagi o wojnie i śmierci, [w:] tenże, Pisma..., s. 48.

Tamże, s. 37.

S. Freud, Totem i tabu, s. 275. 
Działanie grupowe jest dla Freuda ważnym wyrazem ludzkiego barbarzyństwa, państwo samo w sobie pozwala na złe uczynki i przemoc, „do której prawa odmówiono by jednostce" ${ }^{\text {}}$. Moralność narodów pozostaje na relatywnie prymitywnym poziomie. Freud odrzuca Wilsonowskie złudzenie, że wojny mogą służyć jakiemuś celowi etycznemu. Są raczej negacją wszelkich celów etycznych, są brutalną terapią szokową dla cywilizacji, która nazbyt się rozwinęła. Najbardziej heroiczne działania nie są decyzjami podejmowanymi w imię „pewnych dóbr abstrakcyjnych i ogólnych”, lecz po prostu jako odpowiedź na presję wywieraną przez to, co nieświadome ${ }^{63}$. Poświęcenie się dla ojczyzny nie jest szlachetne. Psychoanalitycy wyjaśniają je poprzez „pragnienie śmierci" i inne wzory sadyzmu.

Wielu czytelników może sympatyzować z Freudowską odrazą wobec przemocy politycznej i idealizmu grupowego. Freud jednak błądzi w swej próbie zgłębienia psychologii żołnierza. Dla skromnego żydowskiego lekarza, wiodącego żywot wiedeńskiego cywila w czasie pierwszej wojny światowej, „tajemnica bohaterstwa” jest swego rodzaju obłędem. Żołnierz jest postacią obłąkaną, opętaną przez instynktowny heroizm, czy raczej - nierozwagę, która nie ma moralnej motywacji i niemądrze „wierząc po prostu zapewnieniu [...] stawia czoło wszelkiemu niebezpieczeństwu" ${ }^{64}$. Człowiek owładnięty przemocą nie jest jednostką, lecz nosicielem archaicznych, subindywidualnych impulsów. Jest on inną wersją człowieka masowego, gotową natychmiast porzucić kontrolę nad własnym ,ja idealnym”. Freud oczywiście upraszcza sprawę. Zakładając, że ,ja idealne” nie ma bezpośredniego znaczenia w wojnie, pomija on przerażający fakt, że masowy mord często nie mógłby się dokonać, gdyby nie silne ,ja idealne” i pozytywna identyfikacja $\mathrm{z}$ ideałami narodowymi ${ }^{65}$. Jak sam zauważa, okrucieństwo zazwyczaj łączyło się z pokutą po dokonanym mordzie, wypełnianą, by uśmierzyć poczucie winy ${ }^{6}$. Doskonały, nowoczesny zabójca nie podziela poczucia winy swoich okrutnych poprzedników nie dlatego, że zrzucił wszystkie moralne skrupuły, lecz dlatego, że jego prywatność jest zbyt mocno oddzielona od moralności publicznej, w której uczestniczy. Jak z przekonującą prostotą wyjaśnia Freud, żołnierz wykorzystuje swoje „to”, by walczyć, natomiast państwo, które

Tenże, Aktualne uwagi..., s. 30.

Tamże, s. 46.

Tamże.

65. Dlatego też często powiada się, że powodem tego, iż Włosi są kiepskimi żołnierzami w porównaniu do Anglików czy Niemców, jest słabsza kontrola ,ja idealnego”.

66 S. Freud, Aktualne uwagi..., s. 45. 
prowadzi wojnę, jest w większym stopniu zbiorem brutalnych archaicznych dążeń aniżeli wcieleniem ideałów moralnych ${ }^{67}$.

Strach przed państwem wydaje się stać w sprzeczności z autorytarną pochwałą silnych przywódców. W rzeczywistości owa pozorna sprzeczność może zostać rozwiązana przez odniesienie do pewnej ogólniejszej postawy, skupiającej się na jednostce. Niepozbawione janusowego oblicza przekonania Freuda dotyczące życia zbiorowego są w całości podporządkowane obronie jednostki. Krytyka państwa, podjęta choćby w eseju Aktualne uwagi o wojnie i śmierci (1915), opiera się na przyrównaniu go do mas jako siły również miażdzącej osamotnioną świadomość. Z kolei akceptacja represyjności społeczeństwa politycznego, dokonana w innych pismach, towarzyszy porównaniu państwa do jednostki (państwo działające niczym bohater kultury czy nauczyciel moralności) i przeciwstawieniu go masom potrzebującym rządu. Nacisk położony na rolę jednostki stanowi fundament zróżnicowanych wewnętrznie uprzedzeń Freuda, będąc kluczem do jedności jego przekonań.

\section{V}

Freud nigdy nie sformułował prawdziwej psychologii społecznej. W przeciwieństwie do najnowszych prądów współczesnych nauk społecz-

\footnotetext{
Omówiłem tutaj jedynie tę część Freudowskiej psychologii żołnierza i jej brak realizmu, która jest wypowiadana wprost. Jednak pośrednio Freud sformułował wiele subtelnych i prawdziwych rzeczy, które przyczyniają się do zrozumienia fundamentalnego znaczenia morale, nie moralności, jako prawdziwej potrzeby żołnierza. Jego koncepcja wspólnej „identyfikacji” członków grupy wniosła wyjątkowo owocne spostrzeżenia dotyczące neuroz wojennych, zachowania wojsk pod presją itp. Pojęcie „identyfikacji” jest zresztą użytecznym udoskonaleniem „sympatii”, od którego psychologia społeczna bierze swój początek. Freudowscy badacze ducha bojowego społeczeństwa podkreślali raczej znaczenie czynnika wzajemnej identyfikacji ludzi aniżeli identyfikacji z przywódcą. Z całą pewnością wpływ Napoleona, Wallensteina czy nawet generała Pattona nie wyjaśnia jedności wielu podgrup, które tworzą się w armii. Identyfikacja oznacza nie tylko kult bohatera, lecz także żądanie sprawiedliwości i równości - troskę o to, by wszyscy członkowie grupy zgodzili się na równe traktowanie, w celu uniknięcia zawiści, możliwej w wypadku, gdy jeden z nich byłby traktowany w sposób wyjątkowy. Owa identyfikacja wertykalna jest bardzo istotna. Czuć się innym, gorszym lub lepszym, oznacza dla Freuda brak pełnej identyfikacji i w konsekwencji niechęć do podjęcia walki. I tak oto w przypadku Żyda służącego w obcej armii jak pisze Freud, posługując się jednym z wielu dowcipów, przytoczonych w Dowcipie i jego stosunku do nieświadomości - może to oznaczać niechęć do złożenia ofiary z własnego życia. Żydowskie poczucie odrębności kulturowej może czynić z niego kiepskiego żołnierza - jest to, jeśli możemy ukuć tu takie sformułowanie, kompleks Shylocka. Podobne zjawisko trapi wszystkich, którzy odczuwają niską identyfikację z grupą, choćby czarnoskórych żołnierzy odmawiających udziału w walce. Dlatego też z punktu widzenia psychologii możemy zrozumieć próby eliminacji segregacji i zatrzymania nacjonalizacji międzykulturowych lojalności. Oczywiście w pewnych przypadkach chęć uniknięcia walki może wynikać także ze zbieżności różnych motywacji utrudniających identyfikację, wynikających zarówno z poczucia wyższości (jako osoba wyższa kulturowo), jak i niedostatku (w odniesieniu do psychicznej słabości).
} 
nych, w centrum jego zainteresowania pozostawały jednostka i jej instynkty. Polityka dla Freuda jest przede wszystkim czymś, co rozgrywa się w umyśle, analogicznie jest więc podległa tej samej analizie, co ład i nieład wewnątrz jednostki. Freud twierdził, że jego psychologia była zarówno indywidualna, jak i społeczna, owa psychologia indywiduum i społeczności tworzyła jedność ${ }^{68}$. Korespondencja między elementami tej jedności nie jest jednak ekwiwalentna, gdyż Freud zawsze odwołuje się do jednostki, do ukrytych osobistych emocji, by wyjaśniać jawne działania publiczne. Jego zainteresowanie sferą społeczną konsekwentnie odzwierciedla jego namysł nad tym, co jednostkowe. Freud jest przede wszystkim badaczem jednostki, co prowadzi go do przyjęcia wizji jednostki i społeczeństwa w żywym i trwałym konflikcie. W swej teorii, na różnych poziomach analizy, wspiera on roszczenia obu stron. Zauważmy, że pyta nie tylko, jak jednostka znosi porządek społeczny, ale także o to, w jaki sposób porządek społeczny akceptuje jednostkę. W dzisiejszych czasach pierwsze pytanie uznaje się za kluczowe, lecz dla drugiego wielu z nas straciło już cierpliwość. Utrzymuje się dzisiaj, że jednostka jest jedynie ideologicznym wynalazkiem zachodniej kultury, przez co traci swój powab w obliczu rozwoju technologicznego czy nowych teorii socjologicznych. Siły jednostki i społeczeństwa nie wydają się wyrównane, a rezultat ich zmagań jest w każdym przypadku łatwy do przewidzenia ${ }^{69}$. Freud nie może więc zostać uznany za psychologa społecznego, skoro obecnie opiera się ona na założeniu, że jednostka jest zniewolona przez społeczeństwo. Psychologia społeczna skłania się dzisiaj raczej ku stanowisku organicystycznemu i dlatego też nie mieści się w ramach liberalnej obrony jednostki, do której historycznie należy psychologia Freudowska.

Oczywiście autor Totemu i tabu wyznacza społeczeństwu niezbędne zadanie cywilizacyjne, polegające na podjęciu wysiłku ujarzmienia aspołecznej jednostki. Niemniej jednak ostateczne podsumowanie wymagań społecznych jako „wyrzeczeń” prowadzi go do oskarżeń, jakie kieruje w stronę cywilizacji. Jego psychologia kwestionuje ideę organicystyczną, według której jednostki realizują swoją wartość w ramach polis, kościoła, wspólnoty religijnej czy państwa. Uczuciowość, na której opierała się idea organicystyczna, podupadła już w dziewiętnastym wieku. Odczucia Freuda były więc już kształto-

S. Freud, Psychologia zbiorowości..., s. 53.

Często neguje się twierdzenie, że taki konflikt jest w ogóle konieczny. Tak różni oponenci, jak marksiści czy neofreudyści zgodnie korzystali z obrazu aspołecznej, antagonistycznej „natury” ludzkiej skierowanej przeciwko represyjnemu „społeczeństwu” jedynie jako konsekwencji patologii, występujących w nowoczesnym społeczeństwie kapitalistycznym. Utrzymywali oni, że w istocie interesy jednostki i społeczeństwa nie stoją tak naprawdę w sprzeczności. Por. F. H. Bartlett, Sigmund Freud: A Marxian Essay, London 1938; E. Fromm, The Sane Society, New York 1955, s. 74-77. 
wane przez dominującą doktrynę indywidualizmu, według której „społeczeństwo" wymagało od jednostki poświęceń, a nie, jak we wcześniejszych koncepcjach wspólnoty organicznej, umożliwiało jej spełnienie. Wspomniana obrona jednostki jako ciała obcego we wielkiej wspólnocie jest powodem do chluby dla Nietzschego i Stirnera w ich psychologizujących filozofiach. Jej echa powracają także u Freuda w jego terapeutycznej próbie rozdzielenia prywatnych uczuć od ich neurotycznego przesunięcia w obręb władzy publicznej. Spośród wielkich psychologów moralnych dziewiętnastego wieku jedynie Bentham był w stanie pogodzić jednostkę i dobro społeczne. Na tym właśnie zasadza się utopizm jego i innych liberalnych doktryn, identyfikujących dobro jako największe szczęście dla jak największej liczby ludzi. Freud widzi tutaj jednak antagonizm. W ramach w pewnym stopniu romantycznego skojarzenia wyrzeczenia $\mathrm{z}$ dobrym zachowaniem dostrzegł on trwałą opozycję jednostki i społeczeństwa. Przedmiotem psychologii Freuda są więc koszty poświęcenia przez jednostkę swojego szczęścia na rzecz moralnej tyranii społeczeństwa. Społeczna idea dobra staje się przedmiotem badania psychiatry.

W tym właśnie dokonuje się zdumiewiająca inwersja namysłu tradycyjnego: idee moralne stają się problemem życiowym, a nie podstawą rozwiązania takich problemów. W silnej podejrzliwości wobec poświęcenia, porównywanego z chorobą, kryje się niechęć do społecznego idealizmu jako sposobu symbolicznego przedstawiania i maskowania władzy. Doktryna Freuda stawia zaspokojenie ponad osiągnięciami. Kwiestonuje te ostatnie, pytając przede wszystkim, do jakiego zadowolenia one prowadzą. Aby zrealizować jakiekolwiek wyznaczone zadania, konieczny jest pewien kompromis zawarty w imię skuteczności działania. Problem rzeczywistej wartości i formy tego kompromisu jest przedmiotem badań psychoanalizy zarówno jako doktryny, jak i terapii. Freudyzm przekonuje zatem, że kultura wyższa wymaga inwentaryzacji, sprawdzenia kosztów, jakie generuje.

Freud poprzez obronę jednostki przez nieuniknionymi ujarzmieniami, nie mając do niej wielkiego zaufania, wyraża głęboką ambiwalencję wobec wspólnoty politycznej. Jej moc okaleczania jednostki może zostać umniejszona dzięki analizie pochodzenia władzy zbiorowej, podejmowanej choćby dlatego, że jej legitymacja nie jest już uznawana za oczywistą. Liberalizm Freuda to doktryna rozwinięta w takim stopniu, że działa jak lekarstwo na swoje własne bolączki, próbując godzić antagonizm pomiędzy naciskiem społecznym a pragnieniem prywatnym. Życie społeczne analizowane jest w czasach, gdy nie szanuje się już prawa jednostki do zaspokojenia.

Negatywna ocena państwa, mas, tłumu, mrowia kultur wrogich samotnej osobistej mądrości jest dokonywana z punktu widzenia terapeutycz- 
nego zainteresowania jednostką. Przeciwstawione zaangażowaniu w kulturę, przeniknięte Schopenhauerem i Nietzschem, zdradza ono wyraźnie Ducha Czasów. W tym znaczeniu Freud rzeczywiście jest ukrytym elitarystą. Przedmiotem jego kuracji są osoby ukształtowane, świadome swej indywidualności i przekonane do instynktownej natury. Owa wyrobiona indywidualność jest oznaką dojrzałości, nie daną nam od początku z samej natury. Freud nie pokazuje nam jednostki, która buntuje się w imię demokratycznych uczuć, odczuwając zarazem erotyczną jedność z rodzajem ludzkim oraz dumne poczucie odosobnienia, lecz świadomego i roztropnego człowieka, który wyzwolił swój umysł spod wpływu autorytetu i dlatego nie płaci dłużej ceny konfliktu i neurozy.

Nie chcę przez to powiedzieć, że psychoanaliza Freuda miałaby się stać, co nastąpiło w jej późniejszych wersjach, etyką adaptacji społecznej. Jednak zalecana roztropność wydaje się bliska pewnemu przeformułowaniu tego typu etyki. W charakterze ukształtowanym przez psychoanalizę możliwa jest uległość wobec żądań społeczeństwa, jeśli wynika ona z obrachunku osobistych potrzeb, a nie ze szczerego entuzjazmu. Psychoanaliza wspomaga zatem racjonalne wyobcowanie, wyłączające jednostkę z publicznych uniesień. Wyobcowana racjonalnie osoba uczy nas, jak strzec się przed zbytnim zaangażowaniem społecznym, a jednocześnie jak je podejmować, kiedy jest to konieczne. Przesłanie społeczne Freuda ma więc charakter racjonalny i manipulacyjny. Choć freudyzm może sam funkcjonować jako ideologia, wpaja nam, jak starałem się pokazać, sceptycyzm wobec wszystkich ideologii poza tymi, które dotyczą wyłącznie życia prywatnego.

Psychoanaliza jest doktryną człowieka prywatnego, broniącego owej prywatności przed ingerencją sfery publicznej. Pielęgnuje on radości życia osobistego, a jeśli bierze udział w sprawach publicznych, czyni to świadomie, z prywatnych pobudek. "Jak dalece sprzyja to moralnemu rozwojowi człowieka?" - pyta nas historyk Burckhardt, nakreślając renesansowy ideał człowieka prywatnego. Jego odpowiedź brzmi, że „odnosi on zwycięstwo jako jednostka, lecz jako obywatel przegrywa" ${ }^{\text {,70 }}$. Freud niesie to samo przesłanie. Można go oskarżać o leczniczy egoizm, obecny także $u$ innych dziewiętnastowiecznych obrońców jednostki, chroniących ją przed społeczeństwem, na przykład u Nietzschego czy Stirnera. Właściwą miarą psychologii jest zdrowie jednostki, a nie doskonałość społeczeństwa. Choć natura w koncepcji Freuda nie jest tożsama ze świadomymi celami człowieka, jest także daleka od celów i znaczenia społeczeństwa. Na zimną naukową doktrynę natury

${ }_{70}$ Narodziny człowieka psychologicznego następują równolegle do powstania państwa nowożytnego, które scentralizowało całą władzę. Hobbes, pierwszy absolutystyczny filozof polityki, jest zatem także pierwszym filozofem człowieka prywatnego. 
ludzkiej, wolnej od wartościowania i niezależnej od przedmiotu swego badania, Freud nałożył doktrynę człowieka żyjącego dla samego siebie. Indywidualna walka człowieka o panowanie nad sobą jest warunkiem osiągnięcia widocznego mistrzostwa. W tej psychologicznej formie zachowana zostaje bezwzględość etyki Darwinowskiej, wchodzącej w wiek społeczeństwa masowego i utrzymującej swoje wpływy po czasie leseferyzmu oraz upadku bezwzględnego ducha kapitalizmu, któremu darwinizm dawał ideologiczne wsparcie.

Nawet w warunkach konformizmu możliwa jest wolność wewnętrzna. Wolność społeczna, niezależnie od swego kształtu, jest dla Freuda tylko metaforą. Wolność może istnieć jedynie w przypadku osoby, u której istnieje właściwa równowaga pomiędzy różnymi częściami psychiki. Poszukiwanie wolności społecznej jest więc powierzchowne, a w zasadzie sprzeczne u swych podstaw. Freud pojmuje wolność i tyranię jako stany umysłu. Każda tyrania polityczna jest mocno przesiąknięta „tyranią psychiczną". Amerykański psychoanalityk Lawrence Kubie definiuje taką tyranię jako „dominację nieświadomych przymusów i lęków". Natura konformizmu nie może zostać ujęta w ramach analizy struktury społecznej czy badania interesów możnych, gdyż tenże konformizm „pojawia się u bogatych i biednych, inteligentnych i głupich, obywateli wspólnoty wolnych i państwa totalitarnego, wierzących i niewierzących" ${ }^{\text {,11 }}$. Psychoanaliza odsłania trywialność wielu współczesnych obaw dotyczących stanu organizacji społecznej, która ma prowadzić do konformizmu. Neguje ona w ogóle problemowość zagadnienia wolności jednostki w społeczeństwie, podkreślając w zamian wagę antypolitycznych, indywidualnych poszukiwań doskonałości, zakotwiczonych w kontekście tak dalekim od wspólnotowego, jak to tylko możliwe. Każda polityka jest obszarem zepsucia zarówno we wspólnocie demokratycznej, jak i państwie totalitarnym. Skoro wolność jest stanem psychicznym (przynależnym zasadniczo jednostce, a nie człowiekowi jako części zbiorowości), jest możliwa do osiągnięcia w każdym społeczeństwie. Mówiąc językiem psychoanalizy, można sobie wyobrazić istnienie wolnych niewolników w Atenach, tak jak zniewolonych mieszkańców Nowego Jorku. Właśnie ten obraz wolności leży u podstaw obojętności wobec polityki, jaki stał się udziałem wielu wykształconych Amerykanów o liberalnych przekonaniach politycznych, urzeczonych freudyzmem. Psychoanaliza, zwracając się ku życiu wewnętrznemu, kwestionuje przyjęte kryteria odróżniania jednego reżimu od innego, pomijając sam problem poszukiwania najlepszego ustroju. W ten sposób Freud podkopuje antyczne problemy filozofii polityki, zastępując ją dociekaniami

L. S. Kubie, Authority and Freedom: Some Insights from Psychoanalysis, „The Journal of Religious Thought", vol. IX, nr 1, 1952-1953, s. 40-47. 
psychologii politycznej, skupionymi na pytaniach, w jaki sposób i w jakim stopniu jednostka musi być ograniczana w swych relacjach społecznych.

PRZE七OŻYŁ M A R I N P O LA K OW S K I

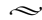

I

MARCIN POLAKOWSKI

Wydział Humanistyczny UMK

\section{Polityk jako terapeuta}

W

ydarzenia lat 60. w Ameryce wywołały reakcję nie tylko wśród amerykańskich elit politycznych. Przemiana kultury i obyczajów społeczeństwa amerykańskiego musiała zainteresować także badaczy społecznych. Owocem tego zainteresowania były przede wszystkim poszukiwania intelektualnych źródeł wydarzeń lat 60 . na różnych poziomach analizy, identyfikowanych zazwyczaj z rozmaitymi nurtami marksizmu, egzystencjalizmu czy freudyzmu.

Zainteresowanie Freudem, a zwłaszcza charakterem, siłą oddziaływania i implikacjami jego myśli społecznej, nie zaczęło się jednak w latach 60 . Jednym $\mathrm{z}$ wielu badaczy, którzy podjelli temat freudyzmu w wymiarze społeczno-politycznym już wcześniej, był Philip Rieff. Celem niniejszego szkicu jest przybliżenie postaci tego zupełnie nieznanego w Polsce, a i nieco zapomnianego w świecie anglojęzycznym myśliciela oraz zasygnalizowanie ważniejszych wątków jego interpretacji współczesnych przemian kultury, społeczeństwa i polityki.

\section{Philip Rieff - przedstawienie postaci}

Philip Rieff urodził się w grudniu 1922 roku, w rok po tym, jak jego rodzice - niezamożni, religijni żydowscy imigranci - przybyli z Litwy do Ameryki i zamieszkali w Chicago ${ }^{2}$. Choć jego rodziców nie było stać na ponoszenie kosztów edukacji wyższej, młody Philip, wyróżniając się zapałem

Niezwykle wpływową pracą inspirowaną Freudem był, jak doskonale wiadomo, Eros i cywilizacja Marcusego. Zob. H. Marcuse, Eros i cywilizacja, przeł. H. Jankowska, A. Pawelski, Warszawa 1998.

Podając podstawowe informacje dotyczące życia Rieffa, opieram się na: A. A. W. Zondervan, Sociology and the Sacred: An Introduction to Philip Rieffs Theory of Culture, TorontoBuffalo-London 2005, zwłaszcza s. 12-24. Książka ta jest zresztą ogólnym i podstawowym omówieniem teorii Rieffa. 